\title{
Quantification of terrestrial ecosystem carbon dynamics in the conterminous United States combining a process-based biogeochemical model and MODIS and AmeriFlux data
}

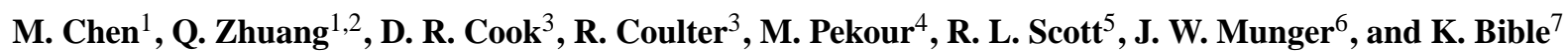 \\ ${ }^{1}$ Department of Earth \& Atmospheric Sciences, Purdue University, West Lafayette, IN, USA \\ ${ }^{2}$ Department of Agronomy, Purdue University, West Lafayette, IN, USA \\ ${ }^{3}$ Climate Research Section, Environmental Science Division, Argonne National Laboratory, Argonne, IL, USA \\ ${ }^{4}$ Atmospheric Sciences and Global Change Division, Pacific Northwest National Laboratory, Richland, WA, USA \\ ${ }^{5}$ Southwest Watershed Research Center, USDA-ARS, Tucson, AZ, USA \\ ${ }^{6}$ Division of Engineering and Applied Sciences and Department of Earth and Planetary Sciences, Harvard University, \\ Cambridge, MA, USA \\ ${ }^{7}$ Wind River Canopy Crane Research Facility, University of Washington, WA, USA
}

Received: 15 February 2011 - Published in Biogeosciences Discuss.: 16 March 2011

Revised: 22 August 2011 - Accepted: 9 September 2011 - Published: 21 September 2011

\begin{abstract}
Satellite remote sensing provides continuous temporal and spatial information of terrestrial ecosystems. Using these remote sensing data and eddy flux measurements and biogeochemical models, such as the Terrestrial Ecosystem Model (TEM), should provide a more adequate quantification of carbon dynamics of terrestrial ecosystems. Here we use Moderate Resolution Imaging Spectroradiometer (MODIS) Enhanced Vegetation Index (EVI), Land Surface Water Index (LSWI) and carbon flux data of AmeriFlux to conduct such a study. We first modify the gross primary production (GPP) modeling in TEM by incorporating EVI and LSWI to account for the effects of the changes of canopy photosynthetic capacity, phenology and water stress. Second, we parameterize and verify the new version of TEM with eddy flux data. We then apply the model to the conterminous United States over the period 2000-2005 at a $0.05^{\circ} \times 0.05^{\circ}$ spatial resolution. We find that the new version of TEM made improvement over the previous version and generally captured the expected temporal and spatial patterns of regional carbon dynamics. We estimate that regional GPP is between 7.02 and 7.78 $\mathrm{Pg} \mathrm{C} \mathrm{yr}^{-1}$ and net primary production (NPP) ranges from 3.81 to $4.38 \mathrm{Pg} \mathrm{C} \mathrm{yr}^{-1}$ and net ecosystem production (NEP) varies within 0.08 $0.73 \mathrm{Pg} \mathrm{C} \mathrm{yr}^{-1}$ over the period 2000-2005 for the conterminous United States. The uncertainty due to parameterization
\end{abstract}

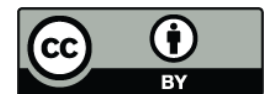

Correspondence to: $\mathrm{M}$. Chen (chenm@purdue.edu) is $0.34,0.65$ and $0.18 \mathrm{PgC}^{-1}$ for the regional estimates of GPP, NPP and NEP, respectively. The effects of extreme climate and disturbances such as severe drought in 2002 and destructive Hurricane Katrina in 2005 were captured by the model. Our study provides a new independent and more adequate measure of carbon fluxes for the conterminous United States, which will benefit studies of carbon-climate feedback and facilitate policy-making of carbon management and climate.

\section{Introduction}

Quantification of net carbon exchanges between the terrestrial ecosystems and atmosphere is scientifically and politically important. It can help improve our understanding of the feedbacks between the terrestrial biosphere and atmosphere (Law et al., 2006) and provide critical information to studying long-term biosphere interactions with other components of the Earth system (Potter et al., 2007). The Intergovernmental Panel on Climate Change (IPCC) reported that the continent of North America has been identified as a significantly large fraction of global carbon budget in terms of both source and sink of atmospheric $\mathrm{CO}_{2}$ (Pacala et al., 2001; Gurney et al., 2002; IPCC, 2001). The conterminous United States accounts for most of the North American total, but with a high uncertainty. For instance, Pacala et al. (2001) estimated a carbon sink in the conterminous United States

Published by Copernicus Publications on behalf of the European Geosciences Union. 
is between 0.30 and $0.58 \mathrm{PgC}^{-1}\left(1 \mathrm{Pg}=10^{15} \mathrm{~g}\right)$ over the 1980s. Fan et al. (1998) estimated the North America sink as $1.7 \pm 0.5 \mathrm{PgC} \mathrm{yr}^{-1}$ over the period of 1988 to 1992 , mostly in the south of $51^{\circ} \mathrm{N}$. Analyses based on land use change and inventory databases for the conterminous United States in the 1980s estimated a sink of 0.08 to $0.35 \mathrm{Pg} \mathrm{C} \mathrm{yr}^{-1}$ (Turner et al., 1995; Houghton et al., 1999, 2000; Houghton and Hackler, 2000). Results from the Vegetation/Ecosystem Modeling and Analysis Project (VEMAP) suggested a smaller sink $\left(0.08 \pm 0.02 \mathrm{PgC} \mathrm{yr}^{-1}\right)$ of the conterminous United States from 1980 to 1993 (Schimel et al., 2000). Recently, Potter et al. (2007) estimated a sink of 0.04 to $0.2 \mathrm{Pg} \mathrm{C} \mathrm{yr}^{-1}$ from 2000 to 2004 while Xiao et al. (2008) estimated the sink at $0.68 \mathrm{Pg} \mathrm{C} \mathrm{yr}^{-1}$ over the period 2000 to 2006 using satellite information. Overall, these results have shown great uncertainties, and remarkably, the uncertainty sometimes is larger than the sink itself.

Reducing the uncertainty of large-scale carbon exchanges requires more adequate comprehension to the related biophysical processes. Traditionally, process-based biogeochemical models have been used (e.g. Raich et al., 1991; Potter et al., 1993; Field et al., 1995; Zhuang et al., 2003; Running and Hunt Jr., 1993). These models usually consider carbon fluxes as functions of climatic and biogeochemical factors (McGuire et al., 1992) and are able to estimate carbon fluxes and storage in the ecosystem. However, since the environmental limitation for simulating carbon fluxes is estimated with specific algorithms driven by uncertain environmental variables, biases between the observed and estimated environmental status can introduce uncertainty. In addition, terrestrial biogeochemical model simulations are uncertain due to lacking of large-scale disturbance data (Canadell et al., 2000; Law et al., 2006). Remotely sensed data provide globally consistent and near real-time observations of numerous surface variables as well as the information of the timing, distribution, spatial extent or severity of disturbances at regional and global scales (Zhao and Running, 2008). These satellite data help more adequately quantify carbon dynamics (Coops et al., 1998; Seaquist et al., 2003; Xiao et al., 2004; Sims et al., 2008). These remotely-sensed data are good at estimating carbon assimilation and plant respiration, but not heterotrophic respiration. Satellite-based models alone cannot sufficiently account for vegetation carbon (Xiao et al., 2010) and nitrogen availability (Clark et al., 1999, 2004) while these can be provided by process-based models. Therefore, models that are based on both satellite observations and biogeochemical processes could potentially improve the quantification of carbon dynamics of Gross Primary Production (GPP), Autotrophic Respiration $\left(R_{\mathrm{A}}\right)$ and heterotrophic respiration $\left(R_{\mathrm{H}}\right)$. For example, Potter et al. (2003) retrieved major disturbances at a global scale with the AVHRR FPAR data for the period of 1982-1999 and combined them with the NASA-CASA model to estimate the above-ground biomass carbon lost. Hazarika et al. (2005) used MODIS derived Leaf Area Index (LAI) to constrain an ecosystem model (Sim-
CYCLE) and improved the accuracy in estimating global Net Primary Production (NPP). However, limitations still exist in those studies. For example, the NASA-CASA directly modeled NPP but avoided the estimation of the Gross Primary Production (GPP). The MODIS LAI products used for constraining Sim-CYCLE are not directly calculated with surface reflectance but derived with complex algorithms (Myneni et al., 2002) which can cause high uncertainty. Here we conduct a study by combining satellite reflectance data with a process-based biogeochemistry model, the Terrestrial Ecosystem Model (McGuire et al., 1992, 2001; Zhuang et al., 2003; Raich et al., 1991), to quantify the carbon dynamics in the conterminous US for the period of 2000-2005.

Eddy covariance flux towers have been established since the 1990s to provide continuous measurements of ecosystem-level carbon exchanges (Wofsy et al., 1993; Baldocchi et al., 2001). At present, over 400 eddy covariance flux towers are operating on a long-term and continuous basis over the globe (FLUXNET http://daac.ornl.gov/FLUXNET/ fluxnet.shtml). This global network covers a wide range of climate and biome types, and provides probably the best measurements of Net Ecosystem carbon Exchange (NEE) (Xiao et al., 2008). Previous ecosystem models were either estimated or calibrated with annual values of observed carbon fluxes (Raich et al., 1991; Potter et al., 1993) and the time series data of carbon fluxes have not been adequately used. In recent years, a number of studies used eddy flux data in a model-data fusion manner to improve the parameterization and predictability of process-based ecosystem models (e.g. Tang and Zhuang, 2008, 2009; Braswell et al., 2005; Williams et al., 2005; Aalto et al., 2004; Santaren et al., 2007; Wang et al., 2001, 2007). Here we conduct a model-data fusion study with a satellite-based model. We first develop a new version of TEM based on satellite-observed surface reflectance, which is hereafter referred to as SAT-TEM. Second we parameterize the SAT-TEM using flux tower data and compare both SAT-TEM and TEM performance at the site level. Finally, we use SAT-TEM to quantify carbon fluxes in the conterminous United States in comparison with the estimates of a previous version of TEM.

\section{Method}

\subsection{Overview}

In this study, Enhanced Vegetation Index (EVI) and Land Surface Water Index (LSWI) from Moderate Resolution Imaging Spectroradiometer (MODIS), which are of high data quality and accuracy (Justice et al., 2002; Guenther et al., 2002; Wolfe et al., 2002), are incorporated into the processbased biogeochemistry model TEM. Observed data from AmeriFlux sites (AmeriFlux, 2009) are then utilized to improve parameterization of the model and test the model performance. Specifically, we modify GPP formulae in TEM 
by incorporating MODIS EVI and LSWI. We then use a Bayesian Inference technique (Tang and Zhuang, 2009) to parameterize the model. The model is then verified for different ecosystem types with the observed Net Ecosystem Exchange (NEE) and GPP from eddy covariance flux towers of AmeriFlux network. To examine how the new model could improve the carbon flux estimation of TEM, we run both versions of TEM at the same sites with the same driving data sets. The model is finally applied to estimate dynamics of carbon fluxes for each $0.05^{\circ} \times 0.05^{\circ}$ grid cell across the conterminous United States over the period 2000-2005.

\subsection{Modification to the terrestrial ecosystem model}

The TEM is a well-documented process-based ecosystem model that describes carbon and nitrogen dynamics of plants and soils for terrestrial ecosystems (Raich et al., 1991; McGuire et al., 1992, 2001; Melillo et al., 1993; Zhuang et al., 2001, 2002, 2003, 2004). The TEM runs at monthly time step and uses spatially referenced information on climate, elevation, soils, vegetation and water availability as well as soil- and vegetation-specific parameters to make monthly estimates of important carbon and nitrogen fluxes and pool sizes of terrestrial ecosystems. In TEM, GPP is modeled as a function of irradiance of photosynthetically active radiation (PAR), atmospheric $\mathrm{CO}_{2}$ concentrations, moisture availability, mean air temperature, the relative photosynthetic capacity of the vegetation, and nitrogen availability. The freezing and thawing dynamics have also been considered (Zhuang et al., 2003). The formula for calculating monthly GPP is:

$$
\begin{aligned}
\mathrm{GPP}= & C_{\max } f(\mathrm{PAR}) f(\mathrm{PHENOLOGY}) f(\text { FOLIAGE }) \\
& f(T) f\left(C_{\mathrm{A}}, G_{v}\right) f(\mathrm{NA}) f(\mathrm{FT})
\end{aligned}
$$

where $C_{\max }$ is the maximum rate of $\mathrm{C}$ assimilation by the entire plant canopy under optimal environmental conditions; $f$ (PAR) represents the influence of photosynthetically active radiation; $f$ (PHENOLOGY) is monthly leaf area relative to leaf area during the month of maximum leaf area depending on monthly estimated evapotranspiration (Raich et al., 1991); $f$ (FOLIAGE) is a scalar function representing the ratio of canopy leaf biomass relative to maximum leaf biomass (Zhuang et al., 2002) having the similar effect as $f$ (PHENOLOGY) on constraining the estimation of GPP; $f(T)$ is temperature scalar with reference to the derivation of optimal temperatures for plant production and $T$ is monthly air temperature; $f\left(C_{\mathrm{A}}, G_{v}\right)$ represents the effect of $\mathrm{CO}_{2}$ concentrations, where $C_{\mathrm{A}}$ is $\mathrm{CO}_{2}$ concentration in the atmosphere and $G_{v}$ is a unitless multiplier that accounts for changes in leaf conductivity to $\mathrm{CO}_{2}$ resulting from changes in moisture availability. The function $f(\mathrm{NA})$ models the limiting effects of plant nitrogen availability. $f(\mathrm{FT})$ is an index of sub-monthly freeze-thaw to indicate effects of freezethaw dynamics on GPP (Zhuang et al., 2003). In TEM, NPP is defined as the difference of GPP and autotrophic respiration $\left(R_{\mathrm{A}}\right)$ and the net carbon exchange between the ecosys- tems and atmosphere is defined as NEP, a difference between NPP and heterotrophic respiration $\left(R_{\mathrm{H}}\right)$ (Raich et al., 1991; McGuire et al., 1992, 2001; Zhuang et al., 2003).

Satellite vegetation indices are widely used in satellitebased carbon models to represent the fraction of vegetation absorbed PAR (FAPAR) (Prince and Goward, 1995; Running et al., 1999, 2000; Potter et al., 1993; Xiao et al., 2004). For example, the Normalized Difference Vegetation Indices (NDVI), which captures the contrast between the visible-red and near-infrared reflectance of vegetation, has a good linear or non-linear relationship of FAPAR. Recent studies show that EVI (Huete et al., 1997, 2002) calculated from the MODIS could more efficiently dismiss the influence of atmospheric scattering and sensitive to canopy variations (Huete et al., 2002). EVI is believed to be a better choice than NDVI to represent photosynthetic activity of vegetation canopy (Boles et al., 2004; Xiao et al., 2004; Yang et al., 2007) and provides reasonably accurate direct estimates of GPP (Rahman et al., 2005). EVI is a normalized index using the reflectance in the near infrared (NIR), red and blue spectral bands:

$$
\mathrm{EVI}=\frac{2.5\left(\rho_{\text {nir }}-\rho_{\text {red }}\right)}{\rho_{\text {nir }}+\left(6 \rho_{\text {red }}-7.5 \rho_{\text {blue }}\right)+1}
$$

Apart from EVI, Xiao et al. (2004) developed the Vegetation Photosynthesis Model (VPM) which used the Land Surface Water Index (LSWI) to help capture the effects of water stress and leaf phenology. As the shortwave infrared (SWIR) spectral band is sensitive to land surface water content, the LSWI is calculated as the normalized difference between NIR and SWIR spectral bands:

$\mathrm{LSWI}=\frac{\rho_{\text {nir }}-\rho_{\text {swir }}}{\rho_{\text {nir }}+\rho_{\text {swir }}}$

where the SWIR spectral bands may be either $1628-1652 \mathrm{~nm}$ or $2105-2155 \mathrm{~nm}$ for MODIS on board the NASA Terra satellite (Yan et al., 2009; Ratana et al., 2005; Li et al., 2007). In our study, we use the band at $2105-2155 \mathrm{~nm}$ to calculate LSWI.

We therefore adopt the formulae of the VPM for GPP modeling in our revision of TEM. We use water scalar $\left(W_{\text {scalar }}\right)$, phenology scalar $\left(P_{\text {scalar }}\right)$ and EVI to account for the vegetation water stress and phenology as well as absoption of PAR while maintaining the original formulation for nitrogen availability, temperature constraints, and the effect of $\mathrm{CO}_{2}$ concentration. GPP in the new version of TEM (SATTEM) is thus modeled as:

$$
\begin{aligned}
\mathrm{GPP}= & C_{\max } f(\mathrm{PAR}) f(T) W_{\text {scalar }} P_{\text {scalar }} f\left(C_{\mathrm{A}}, G_{v}\right) \\
& f(\mathrm{NA}) f(\mathrm{FT})
\end{aligned}
$$

where $f(\mathrm{PAR})=\mathrm{EVI} \times \mathrm{PAR} /\left(k_{i}+\mathrm{PAR}\right)$ indicates the $\mathrm{PAR}$ absorption and the effect of PAR saturation while $k_{i}$ is the half-saturation value. $W_{\text {scalar }}=(1+\mathrm{LSWI}) /\left(1+\mathrm{LSWI}_{\max }\right)$ where $\mathrm{LSWI}_{\max }$ is the maximum LSWI within the plantgrowing season for individual grid cell. Through our study, 


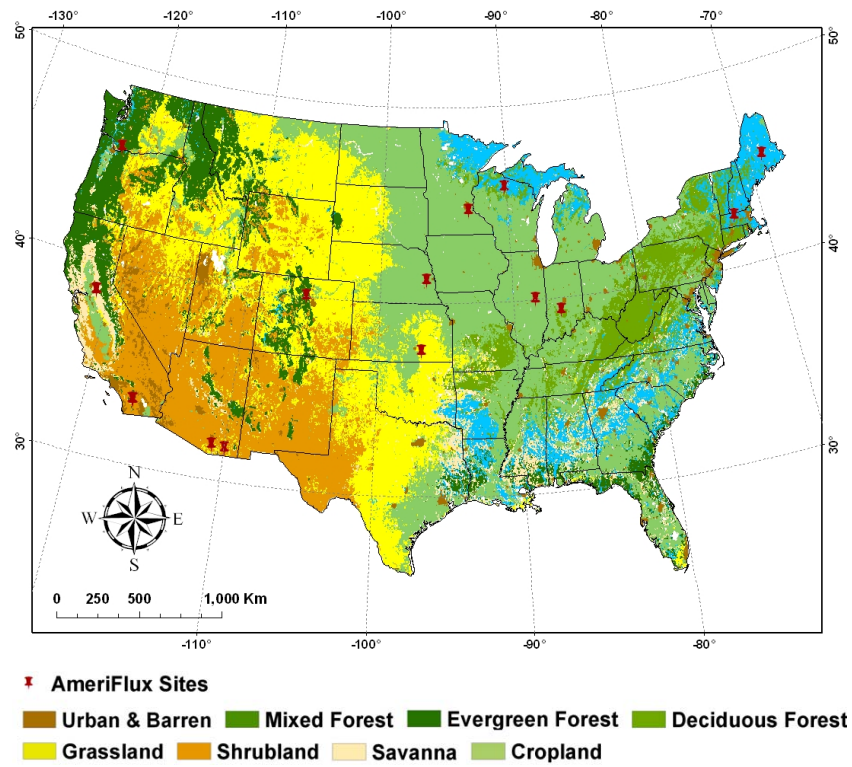

Fig. 1. Land cover map of the conterminous US $\left(0.05^{\circ} \times 0.05^{\circ}\right)$ used in regional simulations. The map was re-classified based on MODIS product Land Cover Types Yearly L3 Global 0.05 Deg CMG (MOD12C1). Red pins indicate the location of the AmeriFlux sites used in this study.

we calculated $\mathrm{LSWI}_{\max }$ in advance and use it as an input parameter for each grid cell in the regional simulation. $P_{\text {scalar }}=(1+\mathrm{LSWI}) / 2$. Specifically, $P_{\text {scalar }}$ is set to be 1 for evergreen vegetations (Xiao et al., 2004). The calculations of NPP and NEP in SAT-TEM are kept the same as the previous version of TEM.

\subsection{Data organization}

\subsubsection{Site-level data}

To drive SAT-TEM model, we first parameterize SAT-TEM using AmeriFlux site observations. We organize the observed GPP, NEP and meteorological data (radiation, air temperature, and precipitation) from six representative eddy covariance flux sites for each vegetation type to parameterize and verify SAT-TEM. In order to further test the performance of SAT-TEM, we organize the same data from ten additional available sites covering all the six vegetation types across most of the conterminous United States (Fig. 1). Specifically, we gather all available monthly Level 4 GPP and Net Ecosystem Exchange (NEE) products (http://public.ornl. gov/ameriflux/) at these sites (Table 1). The Level 4 product consists of two types of NEE data, including standardized (NEE_st) and original (NEE_or) NEE. Corresponding GPP_st and GPP_or are calculated by ecosystem respiration $\left(R_{\mathrm{e}}\right)$ with NEE_st and NEE_or, respectively. GPP_st, GPP_or, NEE_st and NEE_or are filled using the Marginal Distribution Sampling (MDS) method (Reichstein et al., 2005) and the Artificial Neural Network (ANN) method (Papale and Valentini, 2003). We use GPP and NEE calculated from NEE data that were gap-filled using the ANN method (Moffat et al., 2007; Xiao et al., 2008). For each site, if the percentage of the remaining missing values for NEE_st is lower than that for NEE_or, we select NEE_or and GPP_or; otherwise, we use NEE_st and GPP_st. To compare with our TEM simulation, we treat NEE as TEM NEP, but with different signs.

We obtain site-level EVI and LSWI by collecting MODIS ASCII subsets (Collection 5) which consist of $7 \times 7 \mathrm{~km}$ regions centered on the flux tower from the Oak Ridge National Laboratory's Distributed Active Archive Center for each AmeriFlux site. This 16-day product has a spatial resolution of $1 \times 1 \mathrm{~km}$. To better represent the flux tower footprint (Schmid, 2002; Rahman et al., 2005; Xiao et al., 2008, 2010), mean EVI, NIR and SWIR band values for the central $3 \times 3 \mathrm{~km}$ area are extracted within the $7 \times 7 \mathrm{~km}$ cutouts. We only use the pixels with good quality which are determined by the corresponding quality assurance (QA) flags included in the product. LSWIs are then calculated by NIR and SWIR band values. Each 16-day EVI and LSWI values are aggregated into monthly values to correspond with the time step of SAT-TEM.

\subsubsection{Regional spatially-explicit data}

To conduct regional simulations, we organize the regional data of vegetation, soils, topography, and climate at a spatial resolution $0.05^{\circ} \times 0.05^{\circ}$. We obtain land-cover information derived from MODIS product Land Cover Types Yearly L3 Global 0.05 Deg CMG (MOD12C1) (Year 2004) from NASA Goddard Space Flight Center website (http: //modis-land.gsfc.nasa.gov). We use the classification of the International Geosphere and Biosphere (IGBP) land-cover classification system to classify the land cover map of the conterminous United States into 6 major vegetation types, which are used in our SAT-TEM simulations (Table 2 and Fig. 1). EVI, NIR and SWIR bands data are extracted from MOD13C2 (MODIS Terra Vegetation Indices Monthly L3 Global 0.05Deg CMG V005) for the conterminous United States.

Mean monthly climate data including air temperature, cloudiness fractions and precipitation are extracted from NCEP global datasets at a $0.5^{\circ}$ spatial resolution (Kistler et al., 2001). Spatial elevation data and soil texture data from previous studies are from Zhuang et al. (2003). All these data are interpolated into a $0.05^{\circ}$ spatial resolution using Inverse Distance Weighted method to match MODIS data.

\subsection{Model parameterization and application}

We parameterize the SAT-TEM with a Bayesian inference method (Tang and Zhuang, 2009) at the selected six AmeriFlux sites representing every major vegetation type across the conterminous United States. The parameterization method 
Table 1. Characteristics of AmeriFlux sites used in this study.

\begin{tabular}{|c|c|c|c|c|c|}
\hline Site Name & $\begin{array}{l}\text { Latitude } \\
\left({ }^{\circ}\right)\end{array}$ & $\begin{array}{l}\text { Longitude } \\
\left({ }^{\circ}\right)\end{array}$ & Vegetation Type & Years & References \\
\hline Howland Forest West Tower (ME, USA)* & 45.2091 & -68.7470 & Evergreen Forest & $2000-2004$ & Hollinger et al. $(1999,2004)$ \\
\hline Harvard Forest (MA, USA)* & 42.5378 & -72.1715 & Deciduous Forest & $2000-2006$ & Urbanski et al. (2007) \\
\hline Vaira Ranch (CA, USA)* & 38.4061 & -120.9507 & Grassland & 2002-2007 & $\mathrm{Xu}$ and Baldocchi (2004) \\
\hline Sky Oaks New (CA, USA)* & 33.3844 & -116.6403 & Shrubland & 2004-2006 & Lipson et al. (2005) \\
\hline Tonzi Ranch (CA, USA)* & 38.4316 & -120.9660 & Savannas & $2002-2007$ & Ma et al. (2007) \\
\hline Bondville (IL, USA)* & 40.0062 & -88.2904 & Cropland & $2001-2006$ & Hollinger et al. (2005) \\
\hline Niwot Ridge (CO, USA) & 40.0329 & -105.5464 & Evergreen Forest & $2000-2005$ & Monson et al. (2002) \\
\hline Wind River Crane site (WA, USA) & 45.8205 & -121.9519 & Evergreen Forest & $2000-2002$ & Falk et al. (2008) \\
\hline Morgan Monroe State Forest (IN, USA) & 39.3232 & -86.4131 & Deciduous Forest & $2001-2006$ & Schmid et al. (2000) \\
\hline Willow Creek (WI, USA) & 45.8059 & -90.0799 & Deciduous Forest & $2000-2003$ & Cook et al. (2004) \\
\hline Kendall Grassland (AZ, USA) & 31.7365 & -109.9419 & Grassland & $2005-2007$ & Scott et al. (2010) \\
\hline Walnut River (KS, USA) & 37.5208 & -96.8550 & Grassland & $2002-2003$ & Coulter et al. (2006) \\
\hline Sky Oaks Old (CA, USA) & 33.3739 & -116.6229 & Shrubland & 2004-2006 & Lipson et al. (2005) \\
\hline Santa Rita Mesquite Savanna (AZ, USA) & 31.8214 & -110.8661 & Savannas & 2004-2006 & Scott et al. (2009) \\
\hline $\begin{array}{l}\text { Rosemount G21 Conventional Management } \\
\text { Corn Soybean Rotation (MN, USA) }\end{array}$ & 44.7143 & -93.0898 & Cropland & 2004-2006 & Griffis et al. (2008) \\
\hline Mead Irrigated Rotation (NE, USA) & 41.1649 & -96.4701 & Cropland & 2002-2005 & Suyker et al. (2005) \\
\hline
\end{tabular}

* Sites for parameterization.

Table 2. Reclassification of MODIS land covers to TEM vegetation types.

\begin{tabular}{ll}
\hline MODIS Land Cover Types (IGBP) & $\begin{array}{l}\text { Vegetation Community } \\
\text { Type in SAT-TEM }\end{array}$ \\
\hline Evergreen needleaf forest & Evergreen Forest \\
Evergreen broadleaf forest & Evergreen Forest \\
Deciduous needleaf forest & Deciduous Forest \\
Deciduous broadleaf forest & Deciduous Forest \\
Mixed forest & $50 \%$ Evergreen Forest, \\
& $50 \%$ Deciduous Forest \\
Closed shrubland & Shrubland \\
Open shrubland & Shrubland \\
Woody savannas & Savannas \\
Savannas & Savannas \\
Grassland & Grassland \\
Permanent Wetland & Grassland \\
Cropland & Cropland \\
Cropland and natural & Cropland \\
vegetation mosaic & \\
\hline
\end{tabular}

follows the procedures described in Tang and Zhuang (2009). Firstly, 15 key parameters (Table 3) are selected to conduct the parameterization according to our previous sensitivity study (Tang and Zhuang, 2009) and parameterization experiences. To derive the prior parameter sets of SAT-TEM, we first assume that they follow the uniform distributions within previous specified reasonable ranges either based on literature review or our experience. We sample 500000 sets of parameters using the Latin Hypercube Sampling technique (Iman and Helton, 1988) to conduct the Monte Carlo simulations. We then use the sampling importance resampling (SIR) technique with the observed carbon fluxes at the selected sites to draw the posterior from the prior SAT-TEM simulations (Skare et al., 2003) and collect 50000 posterior sets of parameters, which are one-tenth of the prior sample size and are suggested to be able to produce stable results (Green et al., 1999; Tang and Zhuang, 2009). We then divide the errors made by the 50000 sets of parameters into $50 \mathrm{lev}$ els (from the highest error level to the lowest) and sampled 50 sets of parameters, one for each level. These 50 sets of parameters are applied at both sites and the region for ensemble simulations of SAT-TEM to account for the uncertainties of parameterization at different spatial scales. Here the first 2-yr data at all the six sites are used for parameterization while data of the remaining years are used for testing the model. To further test the performance of the SAT-TEM and compare it with TEM independently apart from the parameterization sites, we run both SAT-TEM and TEM at ten additional AmeriFlux sites which represent all six vegetation types within diverse climatic zones across the conterminous United States. Statistics of $R^{2}$ and Root Mean Square Error (RMSE) are calculated to quantitatively evaluate the model performance. The TEM parameters for natural ecosystems are from previous studies (McGuire et al., 1992; Zhuang et al., 2003), parameters for croplands are averaged values for $\mathrm{C}_{3}$ and $\mathrm{C}_{4}$ plants from $\mathrm{Lu}$ and Zhuang (2010). 
Table 3. Key TEM Parameters.

\begin{tabular}{|c|c|c|c|}
\hline Parameter & Definition & Unit & Prior Range \\
\hline$k_{i}$ & Half saturation constant for PAR used by plants & $\mu 11^{-1}$ & {$[100.0,500.0]$} \\
\hline$k_{c}$ & Half saturation constant for $\mathrm{CO}_{2}-\mathrm{C}$ uptake by plants & $\mu 11^{-1}$ & {$[100.0,400.0]$} \\
\hline RAQ10A0 & Leading coefficient of the Q10 model for plant respiration & None & {$[1.0,3.0]$} \\
\hline RAQ10A1 & 1st order coefficient of the Q10 model for plant respiration & ${ }^{\circ} \mathrm{C}^{-1}$ & {$[-0.1,0.1]$} \\
\hline RAQ10A2 & 2nd order coefficient of the Q10 model for plant respiration & ${ }^{\circ} \mathrm{C}^{-2}$ & {$[0,0.005]$} \\
\hline RAQ10A3 & 3rd order coefficient of the Q10 model for plant respiration & ${ }^{\circ} \mathrm{C}^{-3}$ & {$[0.0001,0.001]$} \\
\hline RHQ10 & Change in heterotrophic respiration rate due to $10^{\circ} \mathrm{C}$ temperature increase & None & {$[1.0,3.0]$} \\
\hline MOISTOPT & Optimum soil moisture content for heterotrophic respiration & $\%$ & {$[20,80]$} \\
\hline$C_{\max }$ & Maximum rate of photosynthesis $\mathrm{C}$ & $\mathrm{gC} \mathrm{m}^{-2}$ month $^{-1}$ & {$[500.0,3000.0]$} \\
\hline$K_{r}$ & Logarithm of plant respiration rate at $0^{\circ} \mathrm{C}$ & $\mathrm{gg}^{-1}$ month $^{-1}$ & {$[-9.5,-0.2]$} \\
\hline$K_{d}$ & Heterotrophic respiration rate at $0^{\circ} \mathrm{C}$ & $\mathrm{g} \mathrm{g}^{-1}$ month $^{-1}$ & {$[0.0005,0.007]$} \\
\hline KFALL & Proportion of vegetation carbon loss as litterfall monthly & $\mathrm{g} \mathrm{g}^{-1}$ month $^{-1}$ & {$[0.0005,0.005]$} \\
\hline$N_{\max }$ & Maximum rate of $\mathrm{N}$ uptake by vegetation & $\mathrm{g} \mathrm{m}^{-2}$ month $^{-1}$ & {$[0.1,1.0]$} \\
\hline$N_{\text {up }}$ & Ratio between $\mathrm{N}$ immobilized and $\mathrm{C}$ respired by heterotrophs & $\mathrm{g} \mathrm{g}^{-1}$ & {$[0,0.05]$} \\
\hline NFALL & Proportion of vegetation nitrogen loss as litter-fall monthly & $\mathrm{gg}^{-1}$ month $^{-1}$ & {$[0.001,0.01]$} \\
\hline
\end{tabular}

The parameterized SAT-TEM is then applied to the conterminous United States for the period of 1948-2005 at a $0.05^{\circ}$ spatial resolution with a total of 322287 grid cells. We first run SAT-TEM to equilibrium with the long-term averaged climate and $\mathrm{CO}_{2}$ concentration data from 1948 to 2005 . We then spin-up the model for $120 \mathrm{yr}$ to account for the influence of climate inter-annual variability on the initial conditions of the ecosystems. Since historic climate and $\mathrm{CO}_{2}$ concentration data are not available before 1948, we repeat the data from 1948 to 1987 for 3 times for the spin-up. In addition, since MODIS vegetation index products are only available from 2000, we fill the gap by repeating 2000-2005 MODIS EVI data for the whole period in order to have consistent data for our simulation period. After the spin-up, we run the model with transient monthly climate and annual atmospheric $\mathrm{CO}_{2}$ concentrations from 1948 to 2005 and then extract the results of the period of 2000-2005 for further analysis. To quantify the uncertainty of regional simulation caused by parameterization, we run ensemble SAT-TEM simulations with the 50 sets of parameters obtained from site-level parameterizations. The averaged values and standard deviations of 50 sets of regional results are calculated for analysis. For comparison, we also conduct a regional simulation with TEM.

\section{Results and discussion}

\subsection{Model performance at AmeriFlux sites}

The parameterized SAT-TEM can reproduce the carbon fluxes reasonably well at the six parameterization sites. Comparisons at each individual site show reasonable agreement of seasonality and inter-annual variability between the ob- served and predicted values (Fig. 2, Table 4) except for Sky Oaks New site. Specifically, at forest sites, SAT-TEM simulations better capture the variation of both fluxes of GPP and NEP $\left(R^{2}>0.9\right.$ for GPP and $R^{2}>0.6$ for NEP) when comparing to non-forest sites. SAT-TEM results at Sky Oaks New site however have a relatively lower linear relationship ( $R^{2}=0.10$ for GPP and $R^{2}=0.13$ for NEP) comparing to $R^{2}>0.7$ for GPP at other sites. Literature review (Xiao et al., 2008, 2010; Sims et al., 2008) shows previous satellitebased estimations all failed to capture the variation of carbon fluxes at this site. Apart from the reason of short records at this site, this disagreement is likely due to solar elevation angle effects on spectral reflectance (Sims et al., 2008) since it is reported that surface reflectance as well as NDVI and EVI are strongly affected by diurnal and seasonal changes in solar elevation angle when vegetation is sparse (Goward and Huemmrich, 1992; Pinter et al., 1983, 1985; Sims et al., 2006, 2008). There is also a relatively weak linear relationship between SAT-TEM NEP and observations at Tonzi Ranch site. This may be due to MODIS and tower footprints that do not match with each other at this site according to Ma et al. (2007) and Xiao et al. (2008). Tonzi Ranch site is dominated by deciduous blue oaks and the understory while the MODIS footprint consists of larger area of grassland. Since the phenology of these two ecosystems is distinct from each other, they contribute differently to the integrated fluxes, leading to the error of model predictions.

Overall, performance of SAT-TEM is obviously superior to that of TEM as shown in Table 4 at the six parameterization sites. Statistics of SAT-TEM results have notable higher $R^{2}$ values and lower RMSE at all these sites showing that SAT-TEM has better ability to capture the variations and magnitudes of both GPP and NEP fluxes. The superiority 

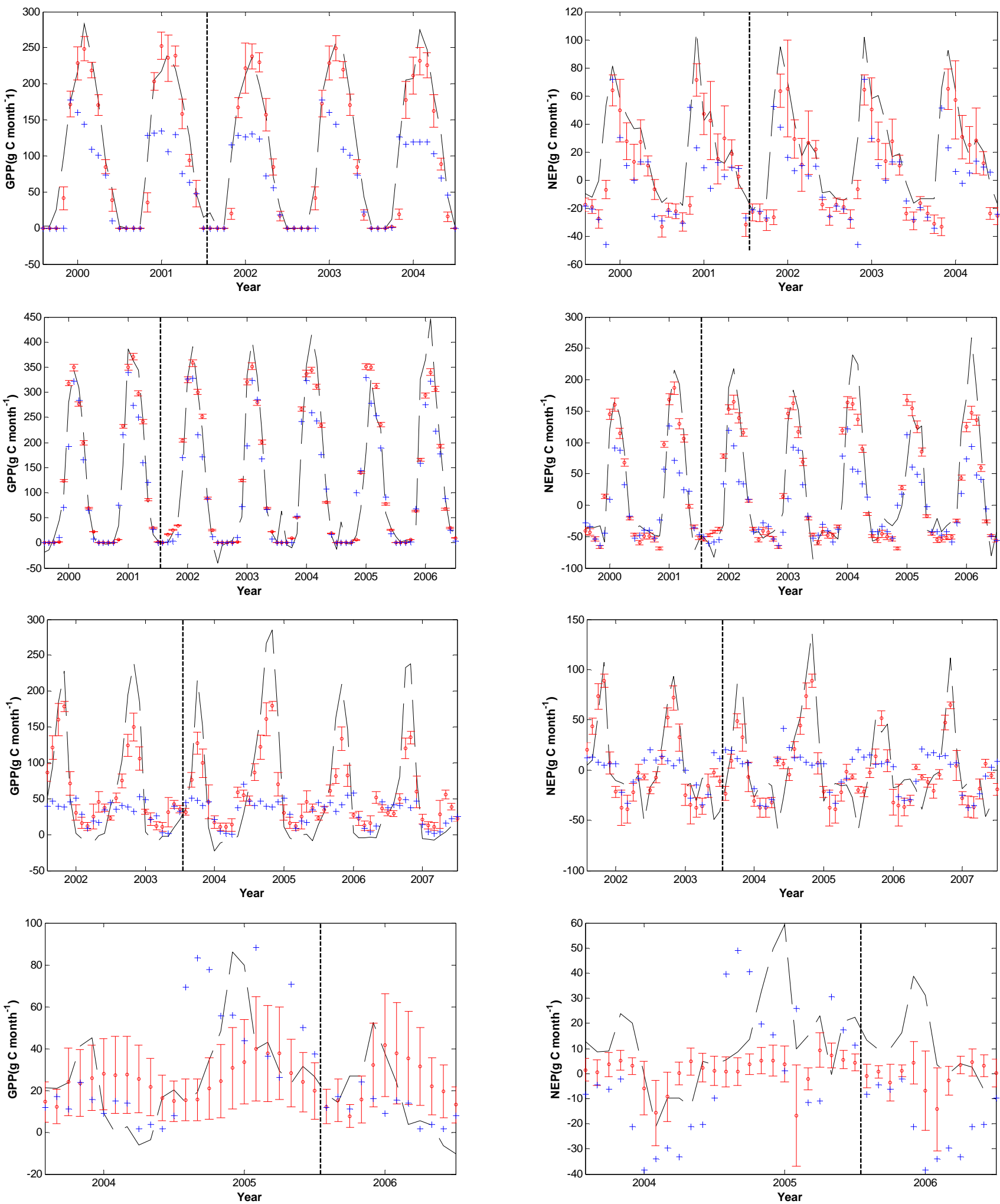

Fig. 2. Comparison of seasonal variations of the observed GPP and NEP with SAT-TEM and TEM predicted ones at the six parameterization sites. Dashed lines are the observations while circles and crosses are the predictions with SAT-TEM and TEM, respectively. The error bars indicates the standard deviation of the results by ensemble SAT-TEM simulations with 50 sets of posterior parameters. Data during the periods before the vertical dotted lines are used for parameterization while the remaining are verification results at: (a) Howland Forest West Tower site; (b) Harvard Forest site (c) Vaira Ranch site; (d) Sky Oaks New site; (e) Tonzi Ranch site; (f) Bondville site. 

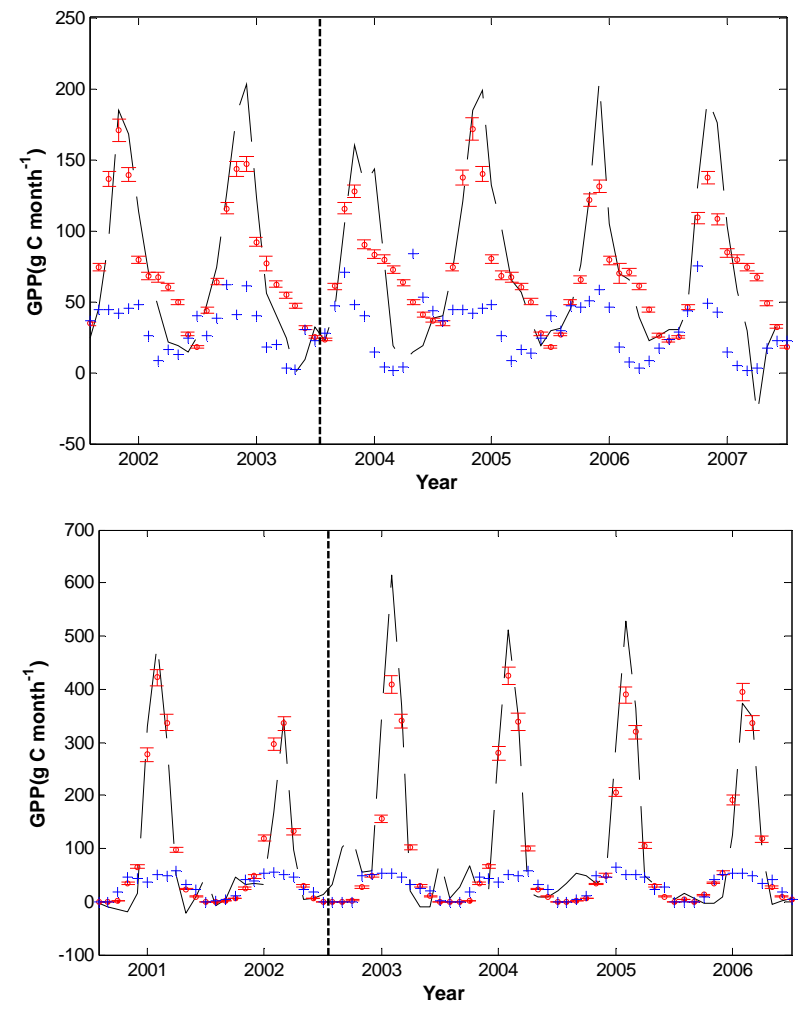

Fig. 2. Continued.

of SAT-TEM is especially reflected at the non-forested sites considering the corresponding poor performances of TEM. This finding may indicate that TEM is better at simulating forest fluxes but weaker at simulating the seasonality and variations of carbon sequestration in non-forested ecosystems where satellite observations may provide a significant help.

Testing at the other ten additional sites generates the similar results (Fig. 3, Table 5). Comparing to the non-forested sites, both SAT-TEM and TEM have promising simulations at the forested sites and SAT-TEM performs overall better than TEM with significantly higher values of $R^{2}$ and lower values of RMSE. SAT-TEM again shows superior performances to TEM at the non-forested sites. Except the shrubland site, the averaged $R^{2}$ of SAT-TEM GPP and NEP at all non-forested sites are 0.68 and 0.27 , respectively. Comparing to 0.41 and 0.12 of TEM, SAT-TEM can better capture the seasonality and inter-annual variability of the carbon fluxes than TEM. SAT-TEM's RMSEs are much lower than TEM's at these sites, indicating that SAT-TEM has better performance. Both SAT-TEM and TEM do not perform well at the only available shrubland site. The Sky Oaks Old site is very close to the parameterization sites, thus the verification result is similar at the parameterization site. However, SATTEM still performs better with higher $R^{2}$ and lower RMSE for both GPP and NEP. The high RMSEs at cropland sites are probably due to the different crop species, the rotations
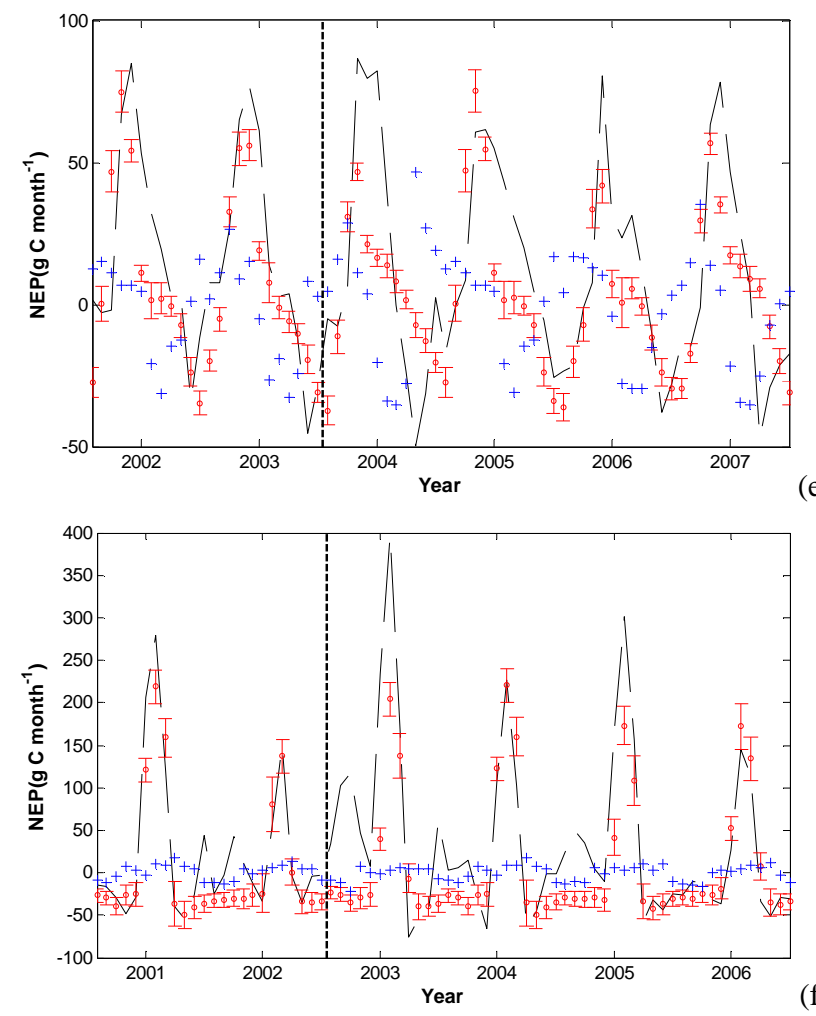

of different crops and the different field managements, which have not been considered in simulations.

SAT-TEM estimated GPP and NEP are under- or overpredicted for some sites. The model could not capture exceptionally high values in the summer at some sites, such as some summer months at the cropland sites (Bondville, Rosemount, Mead Irrigated). Underestimations of NEP also take place in the winters at the Howland site, the springs and the winters at the Wind River Crane site, possibly due to the overestimation of the ecosystem respirations at these two sites. The model also overestimated GPP at the Varia Ranch site in winters. Considering the low quality of GPP in winters (most of them $<0$ ), our estimation could still be in a reasonable range. If we pool all the measured fluxes together (Fig. 4), SAT-TEM shows better performance.

We find the errors introduced by parameterization are relatively small at most sites except at the shrubland sites and evergreen forest sites with SAT-TEM (Figs. 2 and 3). The most significant errors are usually occurring in summer commonly with relatively higher air temperature and abundant solar radiation, and precipitation, which can amplify the differences (Tang and Zhuang, 2008, 2009). Comparing to GPP, the simulated NEP has more significant errors, which is probably due to the error propagation when more parameters are involved in NEP calculation. 
Table 4. Statistical results for the observed and SAT-TEM and TEM predicted monthly GPP and NEP at each AmeriFlux site for parameterization. The units of RMSE are $\mathrm{g} \mathrm{C} \mathrm{m}^{-2}$ month $^{-1}$.

\begin{tabular}{|c|c|c|c|c|}
\hline Site Name & Time Periods & & $R^{2}$ & RMSE \\
\hline \multirow{4}{*}{ Howland Forest West Tower (ME, USA) } & \multirow{4}{*}{ 2002-2004 } & SAT-TEM GPP & 0.94 & 27.24 \\
\hline & & SAT-TEM NEP & 0.65 & 26.84 \\
\hline & & TEM GPP & 0.85 & 64.68 \\
\hline & & TEM NEP & 0.67 & 29.72 \\
\hline \multirow{4}{*}{ Harvard Forest (MA, USA) } & \multirow{4}{*}{ 2002-2006 } & SAT-TEM GPP & 0.90 & 45.62 \\
\hline & & SAT-TEM NEP & 0.83 & 40.84 \\
\hline & & TEM GPP & 0.87 & 58.63 \\
\hline & & TEM NEP & 0.75 & 64.87 \\
\hline \multirow{4}{*}{ Vaira Ranch (CA, USA) } & \multirow{4}{*}{ 2004-2007 } & SAT-TEM GPP & 0.90 & 48.37 \\
\hline & & SAT-TEM NEP & 0.66 & 26.40 \\
\hline & & TEM GPP & 0.23 & 84.13 \\
\hline & & TEM NEP & 0.04 & 44.20 \\
\hline \multirow{4}{*}{ Sky Oaks New (CA, USA) } & \multirow{4}{*}{2006} & SAT-TEM GPP & 0.10 & 19.15 \\
\hline & & SAT-TEM NEP & 0.13 & 19.03 \\
\hline & & TEM GPP & 0.30 & 15.99 \\
\hline & & TEM NEP & 0.01 & 34.21 \\
\hline \multirow{4}{*}{ Tonzi Ranch (CA, USA) } & \multirow{4}{*}{ 2004-2007 } & SAT-TEM GPP & 0.74 & 32.81 \\
\hline & & SAT-TEM NEP & 0.52 & 26.73 \\
\hline & & TEM GPP & 0.20 & 66.61 \\
\hline & & TEM NEP & 0.03 & 46.76 \\
\hline \multirow{4}{*}{ Bondville (IL, USA) } & \multirow{4}{*}{ 2003-2006 } & SAT-TEM GPP & 0.87 & 63.90 \\
\hline & & SAT-TEM NEP & 0.66 & 66.20 \\
\hline & & TEM GPP & 0.50 & 155.33 \\
\hline & & TEM NEP & 0.14 & 103.80 \\
\hline
\end{tabular}

\subsection{Temporal variation of carbon fluxes in the conterminous US}

Annual GPP, NPP and NEP for the conterminous United States over the period 2000-2005 vary from year to year (Table 6). Discrepant results are found comparing to previous studies in the same region and similar time period (Table 7). The SAT-TEM estimated GPP flux varies from 7.02 to $7.78{\mathrm{PgC} \mathrm{yr}^{-1}}$ with of an annual average $7.43 \mathrm{Pg} \mathrm{Cyr}^{-1}$. This estimate is close to $7.06 \mathrm{Pg} \mathrm{C} \mathrm{yr}^{-1}$ estimated by Xiao et al. (2010) over the period 2001-2006 but higher than 6.2 $\mathrm{Pg} \mathrm{C} \mathrm{yr}^{-1}$ of MODIS GPP product (Zhao et al., 2005) for the period of 2000-2005. Our estimate NPP ranges from 3.81 to $4.38 \mathrm{Pg} \mathrm{Cyr}^{-1}$ in this period, which is much higher than the range of $2.67-2.79 \mathrm{Pg} \mathrm{C} \mathrm{yr}^{-1}$ over 2000-2004 from Potter et al. (2007) and the $3.3 \mathrm{Pg} \mathrm{C} \mathrm{yr}^{-1}$ from MODIS NPP product over 2000-2005 (Zhao et al., 2005). Our estimated NEP is $0.08-0.73 \mathrm{Pg} \mathrm{C} \mathrm{yr}^{-1}$ with an average $0.41 \mathrm{Pg} \mathrm{Cyr}^{-1}$. Overall our estimations are higher than 0.04-0.2 $\mathrm{Pg} \mathrm{C} \mathrm{yr}^{-1}$ from Potter et al. (2007), and much lower than the estimates as high as $1.21 \mathrm{PgC} \mathrm{yr}^{-1}$ from Xiao et al. (2011) but our estimation of $0.40 \mathrm{Pg} \mathrm{C} \mathrm{yr}^{-1}$ in 2003 is closer to the estimate of

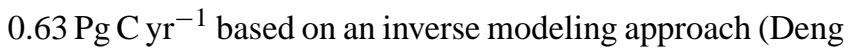
et al., 2007). Comparing to NEP in the 1980s, SAT-TEM estimated a much higher sink than the VEMAP estimate, which put the sink as $0.08 \pm 0.02 \mathrm{Pg} \mathrm{Cyr}^{-1}$, and the landbased analyses (0.08-0.35 $\left.\mathrm{Pg} \mathrm{C} \mathrm{yr}^{-1}\right)$ (Turner et al., 1995; Houghton et al., 1999, 2000), but close to the results (0.30$0.58 \mathrm{Pg} \mathrm{C} \mathrm{yr}^{-1}$ ) provided by Pacala et al. (2001).

SAT-TEM NEP has the similar inter-annual variation to the results presented by Potter et al. (2007) and Xiao et al. (2011) which are higher in 2001, 2003 and 2004 but lower in 2000 and 2002. From 2000 to 2003, the whole region acted as a relatively low net sink of atmosphere $\mathrm{CO}_{2}$ because large area carbon source occurred (Fig. 5). Specifically, in 2000, large carbon sources mainly took place in the south central and southwest area. In 2001, part of the Midwest and South Central, the Rocky Mountain area as well as the Pacific Southwest acted as carbon source. In 2002, large area of the Midwest, the Great Plains and the western US were carbon sources. In 2003, carbon sources mainly took place in the western US, the Rocky Mountain areas and some part of the east and southeast coast. Except for the near-consistent carbon source in the Rocky Mountain 

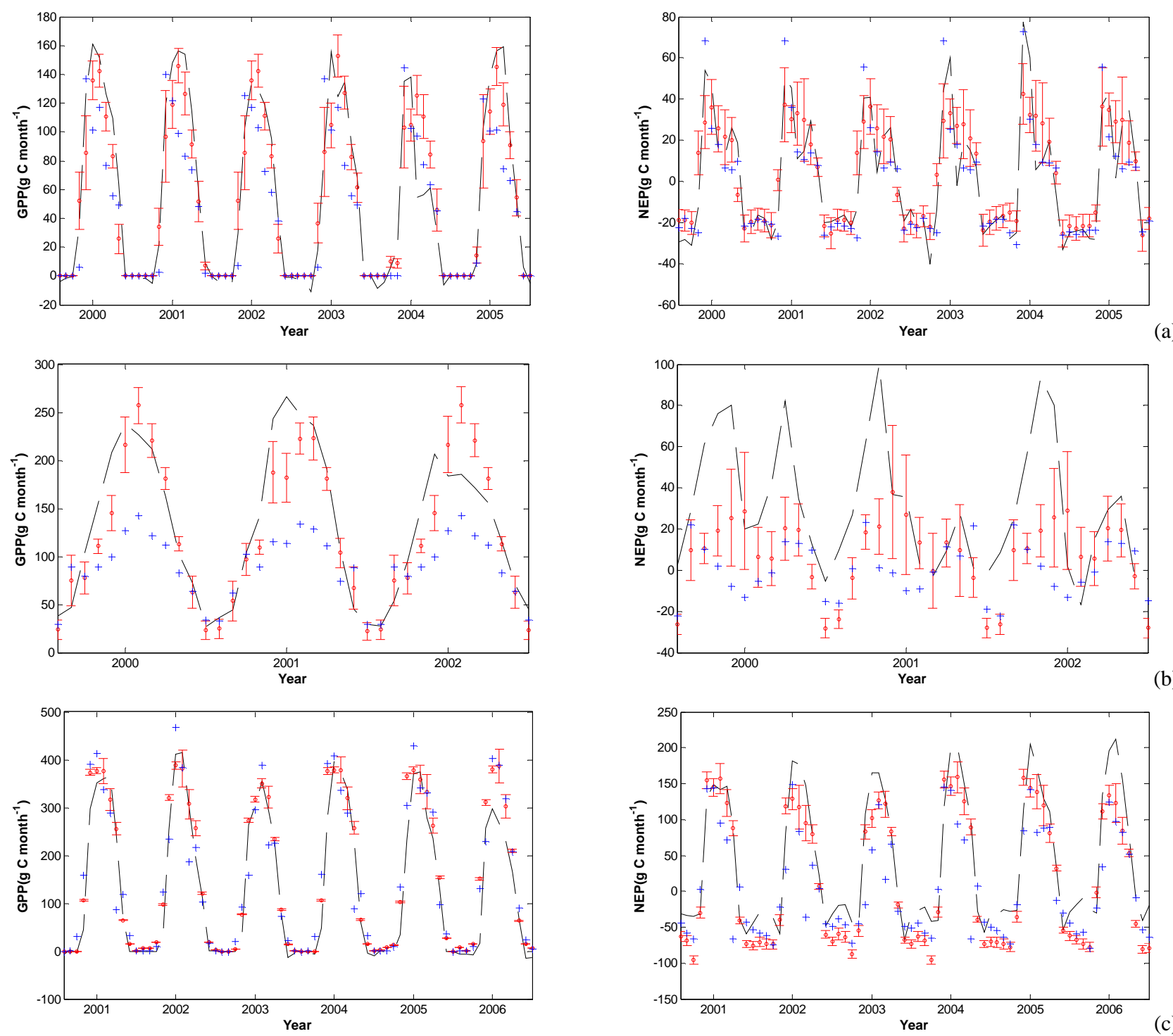

(b)
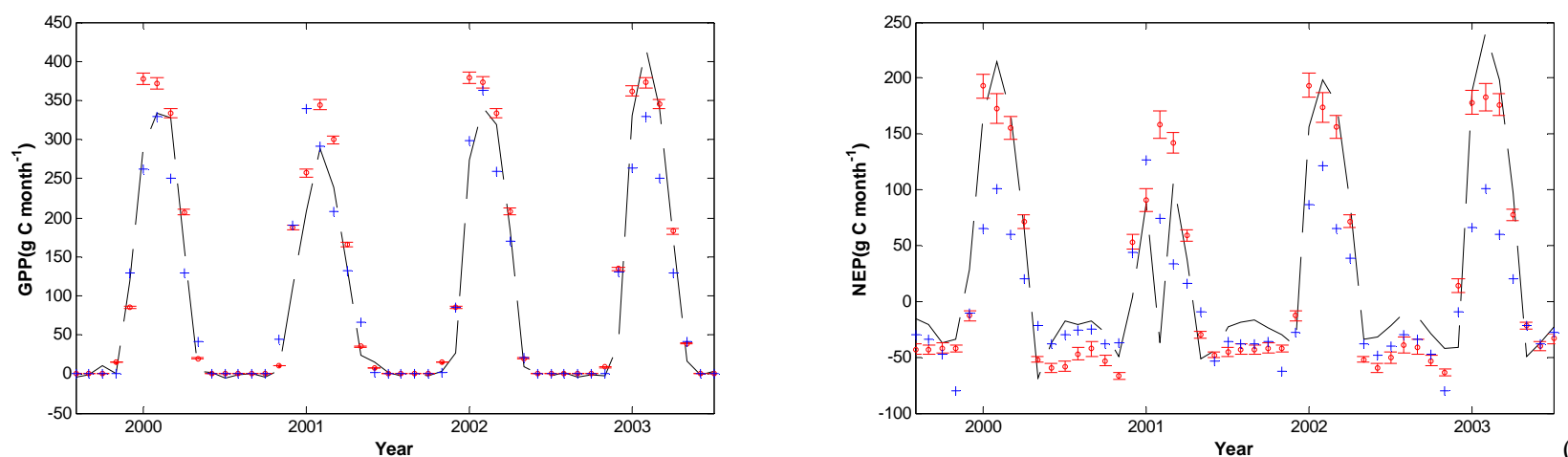

Fig. 3. Comparison of seasonal variations of the observed GPP and NEP with SAT-TEM and TEM predictions at the ten additional AmeriFlux sites. Dashed lines are the observed values while circles and crosses are the predictions with SAT-TEM and TEM, respectively. The error bars indicates the standard deviation of the results by ensemble SAT-TEM simulations with 50 sets of posterior parameters: (a) Niwot Ridge site; (b) Wind River Crane site (c) Morgan Monroe State Forest site; (d) Willow Creek site; (e) Kendall Grassland site; (f) Walnut River site; (g) Sky Oaks Old site; (h) Santa Rita Mesquite Savanna site; (i) Rosemount G21 Conventional Management Corn Soybean Rotation site; (j) Mead Irrigated Rotation site. 

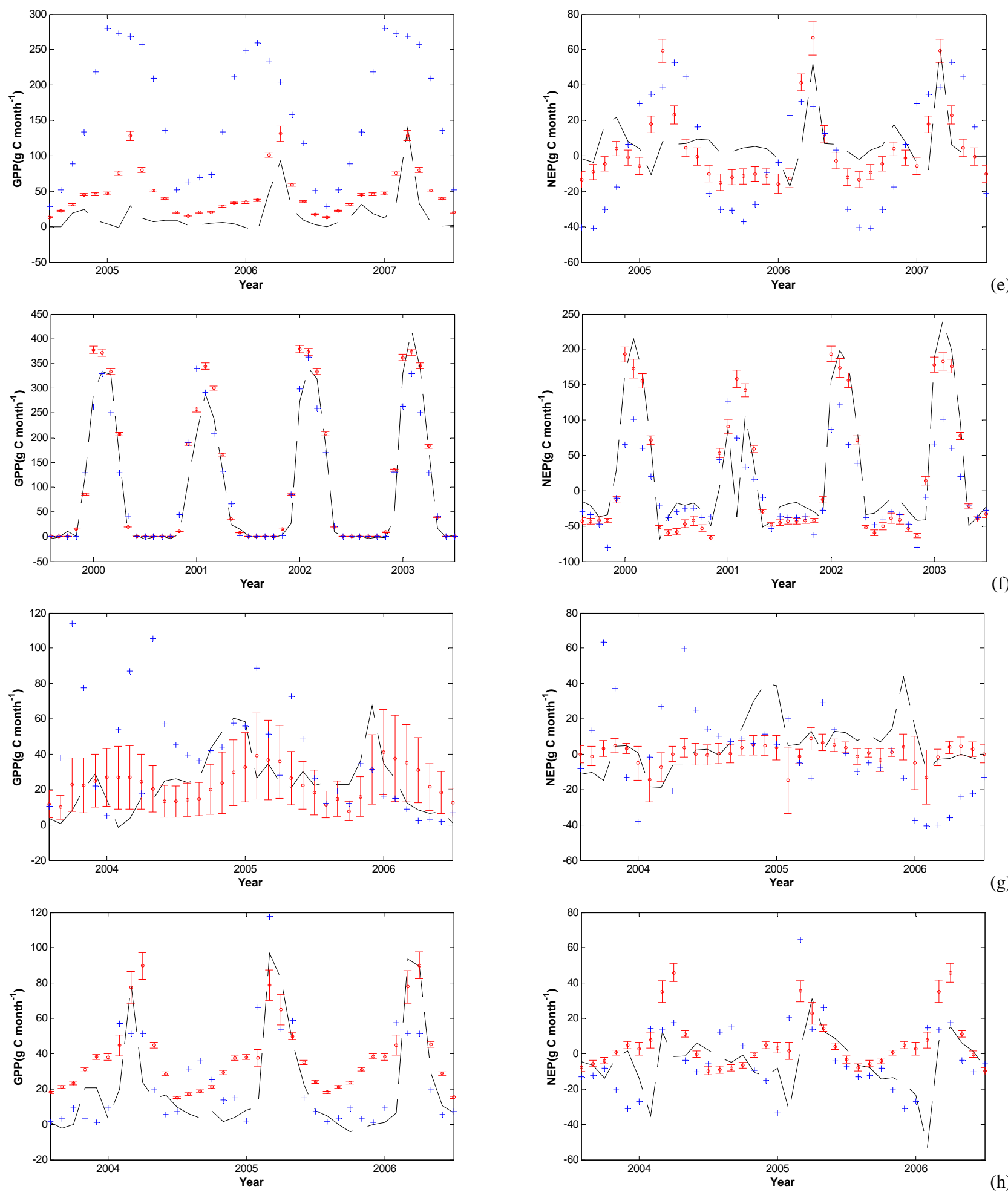

Fig. 3. Continued. 

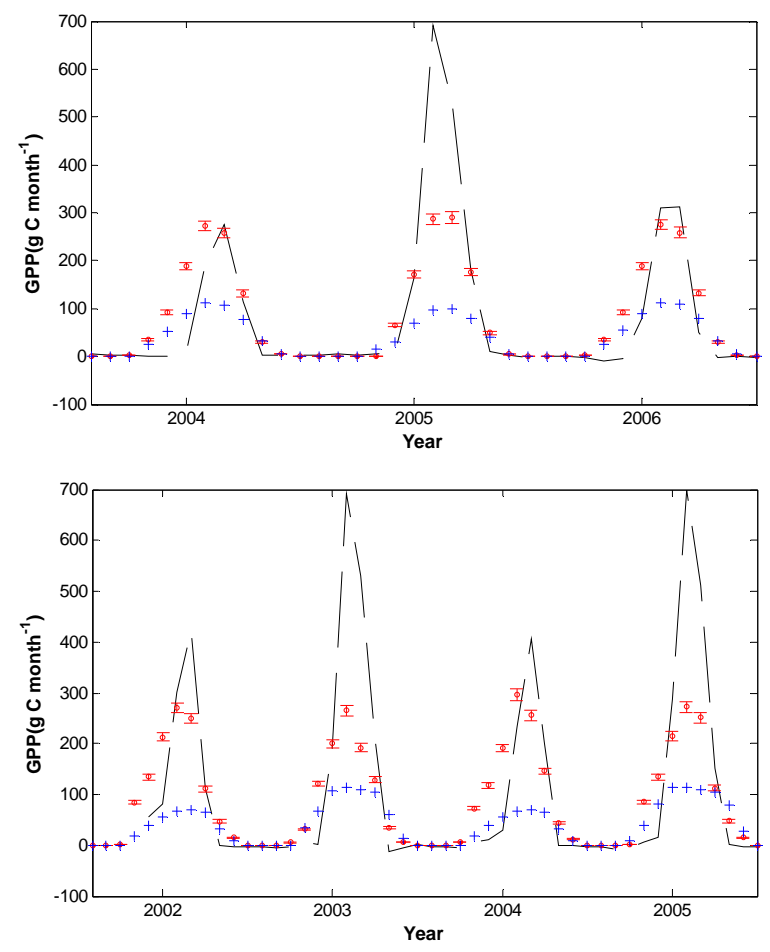

Fig. 3. Continued.

area which is very likely due to cool or cold weather of the highland climate, temperature changes and extreme droughts might be the reason causing the other large area of carbon sources in these years. The National Climatic Data Center (NCDC, http://www.ncdc.noaa.gov/oa/ncdc.html) reported that the contiguous US was very warm during the summer but very cold in November and December in 2000. Southwest states such as Utah, New Mexico and Nevada experienced the second or the third warmest year on record. Apart from the abnormal temperature, the drought in 2000 severely affected much of the southern and western US and therefore reduced the carbon uptake and enhanced the intensity of carbon source. In 2001, the Midwest and Pacific Southwest both had abnormally high temperatures. 2003 was reported as the 20th warmest year on record for the United States. Western regions were reported as much warmer than average for the summer. The Northwest Region had its second warmest summer on record, and the Southwest and West had their third in 2003. Abnormally high air temperature significantly enhances ecosystem respirations but does not contribute much to carbon uptake because the temperature may have passed the range of optimums temperature for plant photosynthesis during the summer time. Consequently, the ecosystem acts as a low sink or becomes a carbon source. Year 2002 had the lowest GPP, NPP and NEP during this period. 2002 was an extreme drought year, in which precipitation was lower than 30 -yr mean annual value. As the year began, moderate to extreme drought covered one-third
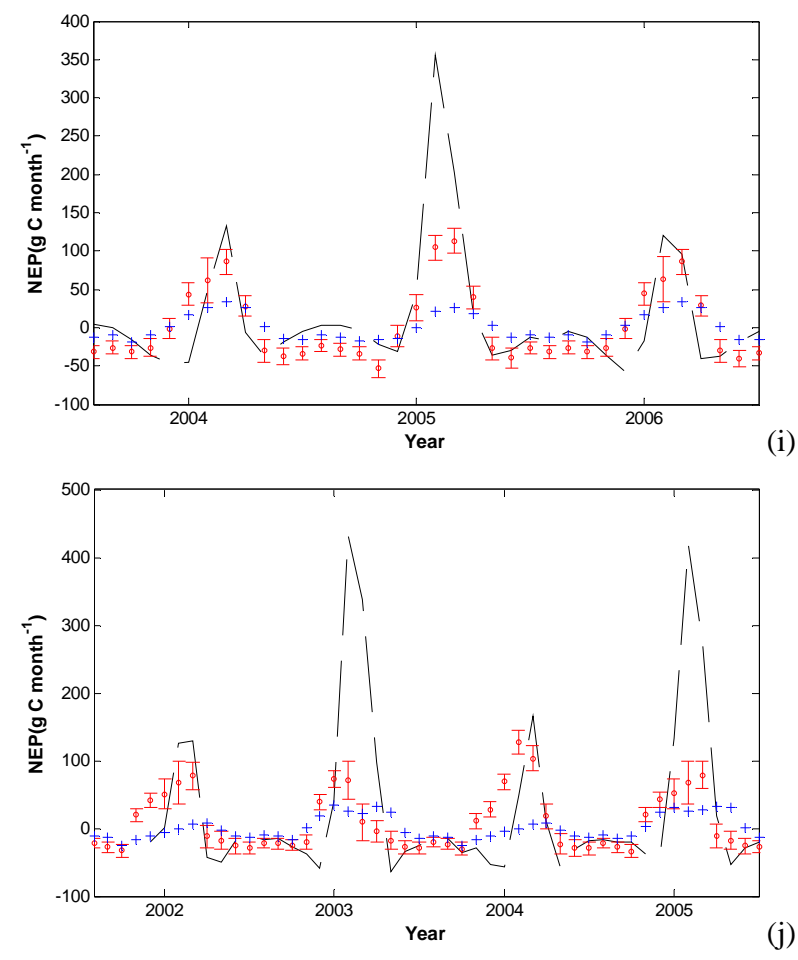

(j) of the contiguous United States including much of the eastern seaboard and northwestern United States. The combination of generally warmer- and drier-than-average conditions led to a large area of carbon source in 2002 (Fig. 5). In addition to the limitations of the carbon uptake, the extreme drought also significantly enhanced the respiration and therefore led to a more severe carbon source. These results suggest that the use of EVI and LSWI is able to reflect the real large-scale environmental conditions and to constrain the estimates of carbon fluxes.

In contrast, the year 2004 had slightly above-average temperatures and was the 6th wettest year on record of the nation (NCDC 2004). The year 2005 was above-average warm but had much lower than average temperatures along the Eastern Seaboard in growing season and the precipitation was near the long-term mean of precipitation in the nation (NCDC 2005). These climate patterns resulted in a high sink in these $2 \mathrm{yr}$ and a carbon source in the eastern regions in 2005.

Seasonality of net carbon uptake of the conterminous United States differed from year to year (Fig. 6a). The accumulative NEP of 2002 did not reach a positive value until early July, which is about one month later than the other years probably due to the severe drought in the spring and summer. Both 2004 and 2005 achieved positive accumulative NEP in the early June while the dates for 2000, 2001 and 2003 were in the midst June. For most of the years, the accumulative NEP started to increase since April, while the date for 2004 is March, indicating the year 2004 turned from 
Table 5. Statistics for the observed and SAT-TEM and TEM predicted monthly GPP and NEP at each AmeriFlux site for parameterization. The units of RMSE are $\mathrm{g} \mathrm{C} \mathrm{m}^{-2}$ month $^{-1}$.

\begin{tabular}{|c|c|c|c|c|}
\hline Site Name & Time Periods & & $R^{2}$ & RMSE \\
\hline \multirow{4}{*}{ Niwot Ridge (CO, USA) } & \multirow{4}{*}{ 2000-2005 } & SAT-TEM GPP & 0.90 & 19.56 \\
\hline & & SAT-TEM NEP & 0.78 & 13.64 \\
\hline & & TEM GPP & 0.83 & 28.10 \\
\hline & & TEM NEP & 0.83 & 12.02 \\
\hline \multirow{4}{*}{ Wind River Crane site (WA, USA) } & \multirow{4}{*}{ 2000-2002 } & SAT-TEM GPP & 0.83 & 32.71 \\
\hline & & SAT-TEM NEP & 0.33 & 34.29 \\
\hline & & TEM GPP & 0.74 & 65.30 \\
\hline & & TEM NEP & 0.09 & 42.06 \\
\hline \multirow{4}{*}{ Morgan Monroe State Forest (IN, USA) } & \multirow{4}{*}{ 2001-2006 } & SAT-TEM GPP & 0.95 & 41.89 \\
\hline & & SAT-TEM NEP & 0.91 & 38.21 \\
\hline & & TEM GPP & 0.88 & 54.13 \\
\hline & & TEM NEP & 0.72 & 59.84 \\
\hline \multirow{4}{*}{ Willow Creek (WI, USA) } & \multirow{4}{*}{ 2000-2003 } & SAT-TEM GPP & 0.96 & 35.15 \\
\hline & & SAT-TEM NEP & 0.83 & 38.62 \\
\hline & & TEM GPP & 0.71 & 55.38 \\
\hline & & TEM NEP & 0.73 & 57.70 \\
\hline \multirow{4}{*}{ Kendall Grassland (AZ, USA) } & \multirow{4}{*}{ 2005-2007 } & SAT-TEM GPP & 0.61 & 37.35 \\
\hline & & SAT-TEM NEP & 0.39 & 17.05 \\
\hline & & TEM GPP & 0.12 & 166.23 \\
\hline & & TEM NEP & 0.02 & 32.60 \\
\hline \multirow{4}{*}{ Walnut River (KS, USA) } & \multirow{4}{*}{$2002-2003$} & SAT-TEM GPP & 0.76 & 57.04 \\
\hline & & SAT-TEM NEP & 0.58 & 25.43 \\
\hline & & TEM GPP & 0.36 & 75.22 \\
\hline & & TEM NEP & 0.02 & 46.99 \\
\hline \multirow{4}{*}{ Sky Oaks Old (CA, USA) } & \multirow{4}{*}{ 2004-2006 } & SAT-TEM GPP & 0.09 & 16.42 \\
\hline & & SAT-TEM NEP & 0.19 & 14.21 \\
\hline & & TEM GPP & 0.01 & 35.57 \\
\hline & & TEM NEP & 0.01 & 30.41 \\
\hline \multirow{4}{*}{ Santa Rita Mesquite Savanna (AZ, USA) } & \multirow{4}{*}{ 2004-2006 } & SAT-TEM GPP & 0.68 & 24.78 \\
\hline & & SAT-TEM NEP & 0.12 & 20.59 \\
\hline & & TEM GPP & 0.50 & 21.87 \\
\hline & & TEM NEP & 0.03 & 22.78 \\
\hline \multirow{4}{*}{ Rosemount G21 Conventional Management Corn Soybean Rotation (MN, USA) } & \multirow{4}{*}{ 2004-2006 } & SAT-TEM GPP & 0.69 & 93.04 \\
\hline & & SAT-TEM NEP & 0.56 & 55.58 \\
\hline & & TEM GPP & 0.51 & 138.89 \\
\hline & & TEM NEP & 0.27 & 73.11 \\
\hline \multirow{4}{*}{ Mead Irrigated Rotation (NE, USA) } & \multirow{4}{*}{ 2002-2005 } & SAT-TEM GPP & 0.66 & 128.83 \\
\hline & & SAT-TEM NEP & 0.29 & 105.89 \\
\hline & & TEM GPP & 0.56 & 180.60 \\
\hline & & TEM NEP & 0.26 & 116.52 \\
\hline
\end{tabular}

a carbon source into a sink earlier than the other years. Accumulative NEP started to decrease in September for all of the years except 2005, which continued to assimilate more carbon than that was released in October and then reverted to a source. The early-beginning and late-ending growing sea- sons for the year 2004 and 2005 led to much higher annual NEP than the other years. Overall, the carbon budget level of the conterminous United States ecosystems can be classified into 3 groups: high sinks in 2004 and 2005, moderate sinks in 2000, 2001, and 2003, and low sink in 2002. 

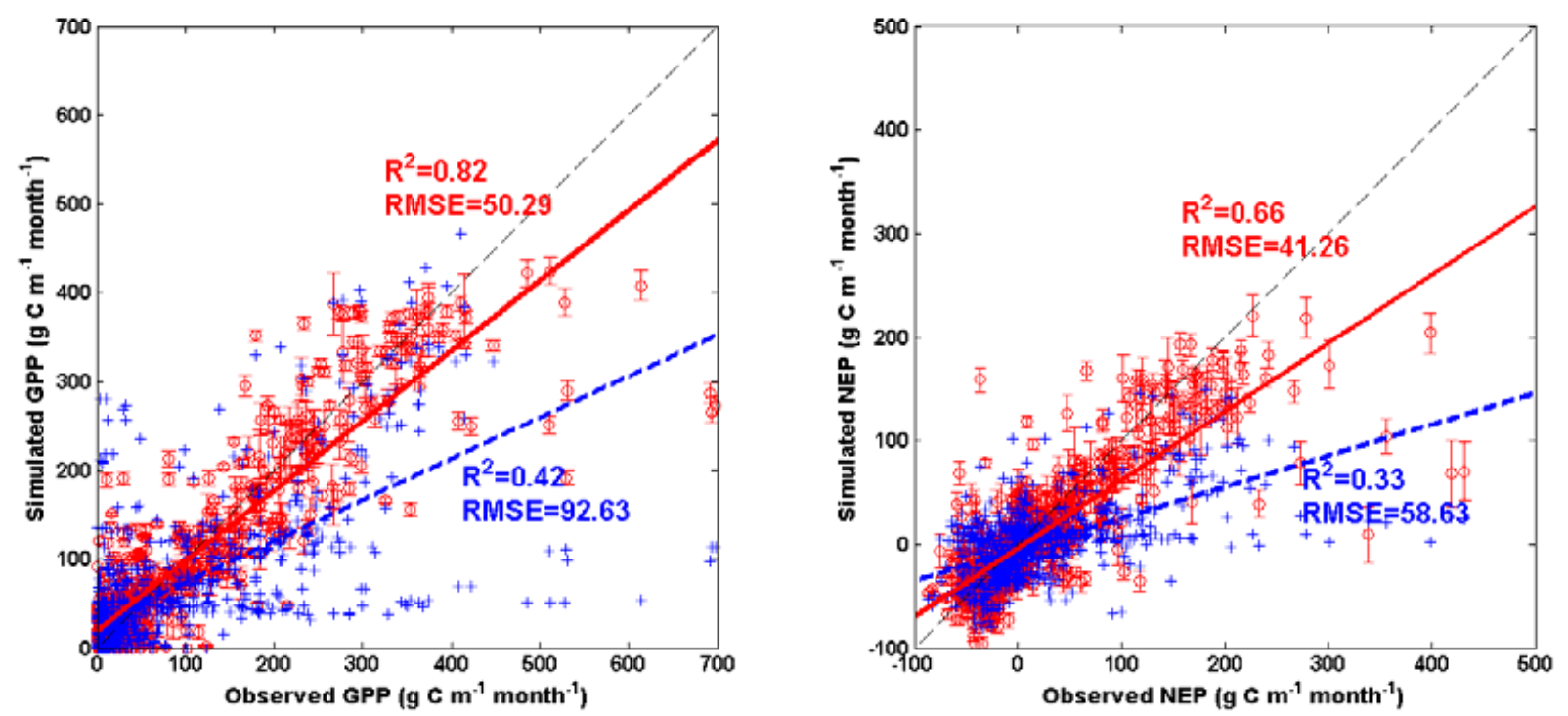

Fig. 4. Scatterplots of the observed GPP and NEP versus SAT-TEM and TEM predictions at the selected AmeriFlux sites. Black dashed lines show a 1:1 relationship. Circles and crosses, red and blue regression lines are SAT-TEM and TEM simulated values, respectively. The error bars indicates the standard deviation of the results by ensemble SAT-TEM simulations with 50 sets of posterior parameters. (a) and (b) are the predicted GPP and NEP versus observed values, respectively.

Table 6. Estimated annual GPP, NPP and NEP across conterminous United States over 2000-2005. The units of the carbon fluxes are

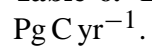

\begin{tabular}{|c|c|c|c|c|c|c|}
\hline \multirow{2}{*}{ Year } & \multicolumn{2}{|c|}{ GPP } & \multicolumn{2}{|c|}{ NPP } & \multicolumn{2}{|c|}{ NEP } \\
\hline & SAT-TEM & TEM & SAT-TEM & TEM & SAT-TEM & TEM \\
\hline 2000 & $7.24 \pm 0.33$ & 8.85 & $3.85 \pm 0.63$ & 4.87 & $0.33 \pm 0.18$ & -0.31 \\
\hline 2001 & $7.35 \pm 0.35$ & 9.32 & $4.06 \pm 0.63$ & 5.27 & $0.41 \pm 0.17$ & 0.02 \\
\hline 2002 & $7.02 \pm 0.34$ & 9.38 & $3.81 \pm 0.62$ & 5.32 & $0.08 \pm 0.17$ & 0.18 \\
\hline 2003 & $7.44 \pm 0.35$ & 10.11 & $4.12 \pm 0.65$ & 5.86 & $0.40 \pm 0.17$ & 0.70 \\
\hline 2004 & $7.75 \pm 0.34$ & 8.96 & $4.38 \pm 0.65$ & 4.96 & $0.73 \pm 0.18$ & -0.19 \\
\hline 2005 & $7.78 \pm 0.35$ & 10.35 & $4.20 \pm 0.69$ & 6.04 & $0.53 \pm 0.18$ & 0.69 \\
\hline Average & $7.43 \pm 0.34$ & 9.49 & $4.07 \pm 0.65$ & 5.39 & $0.41 \pm 0.18$ & 0.18 \\
\hline
\end{tabular}

The seasonality of the regional net carbon uptake can be explained by the satellite-observed vegetation indices. The monthly regional averaged EVI and LSWI vary from year to year (Fig. 6b, c). EVI generally indicates the greenness of the land surface vegetation and shows the pattern of vegetation green-up and senescence. The patterns of regional averaged EVI were similar for the $6 \mathrm{yr}$ but the year 2002 had lower EVI during the green-up period in the spring and the year 2000 had relatively lower EVI during the senescent season. The lower EVI of these two years were reflected by the relatively low NEP in these two years. Particularly, since 2002 was the lowest-sink year, our result may suggest that abnormal EVI in the green-up season led to a stronger influence on the annual total NEP. In contrast, EVI of the year 2004 and 2005 were mostly higher than that of the other years, espe- cially during the summer, which resulted in the highest carbon sink over the 6-yr period. Similar to EVI, the low LSWI from April to August in 2002 indicates that the year 2002 was a drought year and the highest LSWI occurred in the main growing seasons in the years 2004 and 2005, leading to a lower and higher net carbon uptake in the year 2002 and the years 2004 and 2005, respectively. The lowest accumulative EVI and LSWI for the other $5 \mathrm{yr}$ except 2002 in June were 1.40 and 1.53 , while the values in 2002 were 1.40 and 1.39 , respectively. In 2002, the accumulative EVI and LSWI were 1.76 and 1.77 in July, respectively, which exceeded the levels in June of the other years and the region turned into a carbon sink. These suggest that both EVI and LSWI affect the transition of a carbon source to a sink. 
Table 7. Comparison of carbon fluxes between TEM estimated and other existing estimates in the conterminous United States.

\begin{tabular}{|c|c|c|c|c|c|c|}
\hline Method & Reference & Time Period & $\begin{array}{l}\text { Estimated averaged } \\
\text { annual GPP } \\
\left(\mathrm{PgC} \mathrm{yr}^{-1}\right)\end{array}$ & $\begin{array}{l}\text { Estimated averaged } \\
\text { annual NPP } \\
\left(\mathrm{PgC} \mathrm{yr}^{-1}\right)\end{array}$ & $\begin{array}{l}\text { Estimated averaged } \\
\text { annual NEP } \\
\left(\mathrm{PgC} \mathrm{yr}^{-1}\right)\end{array}$ & Comments \\
\hline $\begin{array}{l}\text { SAT-TEM } \\
\text { Ecosystem Model } \\
\text { combining satellite } \\
\text { observations }\end{array}$ & & $2000-2005$ & 7.43 & 4.07 & 0.41 & Estimated in this study. \\
\hline $\begin{array}{l}\text { TEM } \\
\text { Ecosystem Model }\end{array}$ & $\begin{array}{l}\text { McGuire et } \\
\text { al. (1992); } \\
\text { Zhuang et } \\
\text { al. (2003) }\end{array}$ & $2000-2005$ & 9.49 & 5.39 & 0.18 & Estimated in this study. \\
\hline $\begin{array}{l}\text { MOD17 } \\
\text { Remote Sensing } \\
\text { Products }\end{array}$ & $\begin{array}{l}\text { Zhao et } \\
\text { al. (2005); } \\
\text { Running et } \\
\text { al. (2004) }\end{array}$ & $2000-2005$ & 6.2 & 3.3 & & $\begin{array}{l}\text { Aggregated form } \\
\text { MODIS primary } \\
\text { production products } \\
\text { (MOD17) }\end{array}$ \\
\hline $\begin{array}{l}\text { NASA-CASA } \\
\text { Remote sensing driven } \\
\text { ecosystem model }\end{array}$ & $\begin{array}{l}\text { Potter et } \\
\text { al. (2007); } \\
\text { Potter et } \\
\text { al. (1993) }\end{array}$ & $2000-2004$ & & 2.65 & 0.13 & \\
\hline $\begin{array}{l}\text { EC-MOD } \\
\text { Regression tree approach }\end{array}$ & $\begin{array}{l}\text { Xiao et } \\
\text { al. }(2010) \text {; } \\
\text { Xiao et } \\
\text { al. }(2011)\end{array}$ & $2001-2006$ & 7.06 & & 1.21 & $\begin{array}{l}\text { The author presented } \\
0.63 \mathrm{Pg} \mathrm{C}^{-1} \text { as the } \\
\text { total carbon sink for } \\
\text { considering the carbon } \\
\text { assimilated by crops } \\
\text { would be released } \\
\text { back to atmosphere. } \\
\text { We added the cropland } \\
\text { contribution } \\
0.58 \mathrm{Pg} \mathrm{C} \mathrm{yr}^{-1} \text { here to } \\
\text { be consistent with our } \\
\text { study region. }\end{array}$ \\
\hline Nested inverse modeling & $\begin{array}{l}\text { Deng et } \\
\text { al. (2007) }\end{array}$ & 2003 & & & 0.63 & $\begin{array}{l}\text { Calculated by subtract- } \\
\text { ing Canada sink from } \\
\text { the North America total } \\
\text { sink }\end{array}$ \\
\hline
\end{tabular}

Regional estimations between SAT-TEM and TEM differ greatly. The averaged differences are more than 2 and 1.4 $\mathrm{Pg} \mathrm{C} \mathrm{yr}^{-1}$ for GPP and NPP, respectively. NEP of SAT-

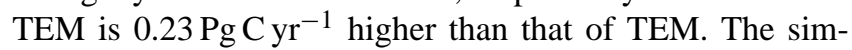
ulated interannual variations between these two versions of TEM are also different. Specifically, SAT-TEM indicated the annual carbon fluxes increased in 2000 and 2001 and dropped to the lowest values in 2002, then kept increasing in the following years and reached the peak values in 2004 and 2005. In contrast, TEM suggested the highest and lowest GPP and NPP occurred in 2005 and 2000, respectively, and the highest NEP in 2003. During these years, TEM might over- or underestimate the water stress and PAR absorption of the vegetation and therefore made different carbon sequestration estimations. However, the more accurate information of the land surface from satellites improves the SAT-TEM simulations. SAT-TEM's performance also benefits from the way of parameterization using the monthly eddy fluxes while TEM was calibrated using annual fluxes only.

\subsection{Spatial variation of carbon fluxes in the conterminous US}

SAT-TEM simulated annual carbon fluxes generally capture the expected spatial patterns (Fig. 7). GPP and NPP have a similar spatial variability from west to east across the conterminous United States. The West Coast, which is dominated by evergreen forest, has high annual GPP and NPP. The western Great Plains and the Rocky Mountain as well as the Southwest regions have relatively low GPP and NPP owing to sparse vegetation and arid climate. Cropland areas in the Midwest have relatively high GPP and NPP probably due to ample irrigation and fertilization. Highest GPP and NPP occur in the east United States with dense vegetation. The Gulf Coast has especially high GPP mainly due to its favorable temperature and abundant precipitation.

Most areas across the conterminous United States have positive NEP from 2000 to 2005. Most forested areas are carbon sinks and the highest sinks take place in the woody 


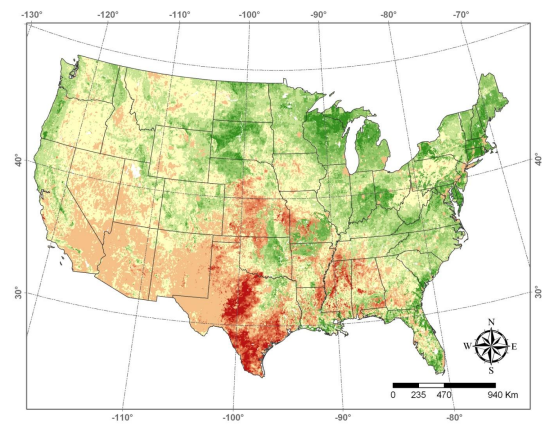

2000

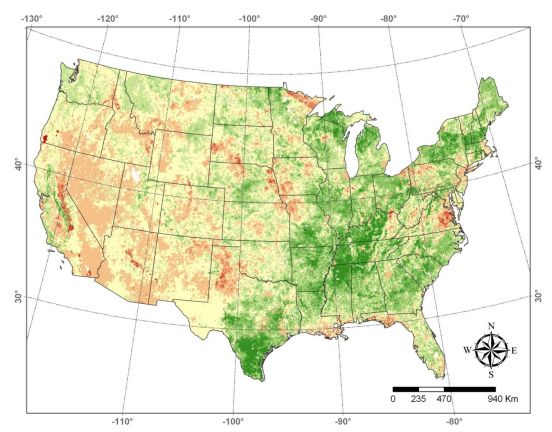

2003

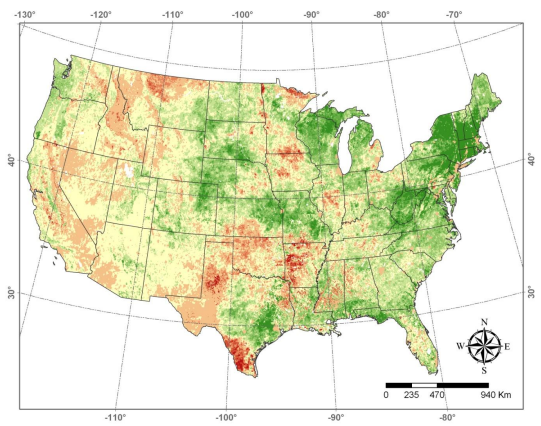

2001

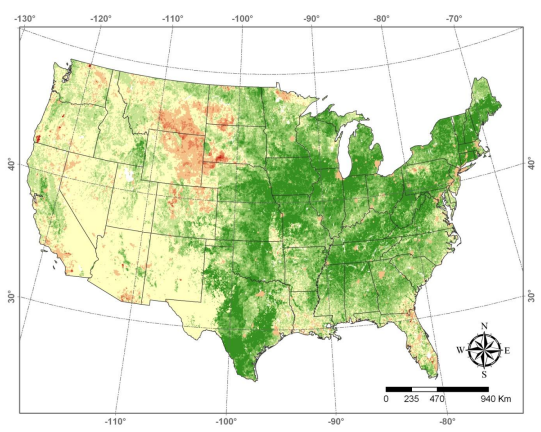

2004

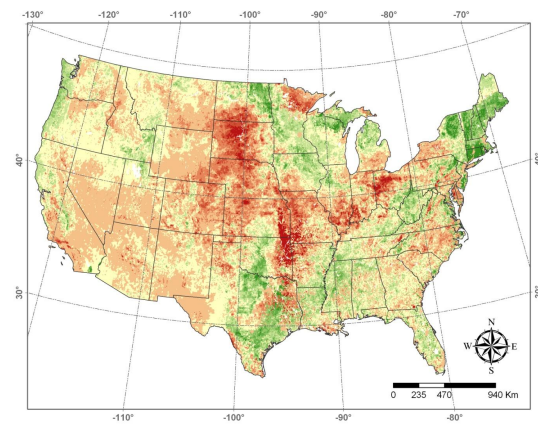

2002

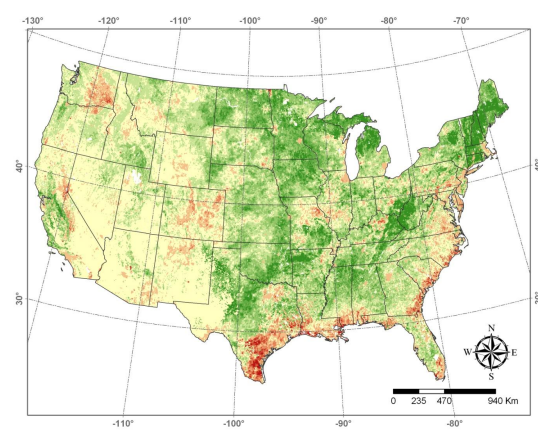

2005

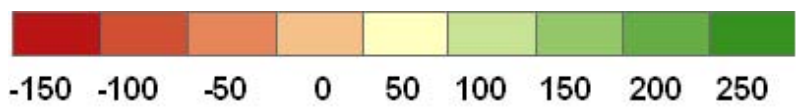

Fig. 5. Annual average SAT-TEM estimated NEP across the conterminous United States for each year in 2000-2005. Positive values represent carbon sink while negative values represent carbon source. Units are $\mathrm{g} \mathrm{C} \mathrm{m}^{-2} \mathrm{yr}^{-1}$.

regions in the eastern United States and especially in the Northeast with intensive radiation, abundant precipitation, warm temperature or dense vegetation cover. But the carbon sources also take place in forest regions, mostly in the south Rocky Mountain area and Sierra Nevada Mountain mainly due to the cold and dry climate. Non-forest regions including grassland, savannas, shrubland as well as cropland act as a carbon sink. Except the year 2000, most area of grassland in the south especially in Texas is a persistent carbon sink with warm weather and abundant precipitation with 100 to $250 \mathrm{~g} \mathrm{C} \mathrm{m}^{-2} \mathrm{yr}^{-1}$ over the 6-yr period. Most cropland areas are carbon sinks with the intensity of 50 to $100 \mathrm{~g} \mathrm{C} \mathrm{m}^{-2} \mathrm{yr}^{-1}$.

Carbon dynamics vary in different ecosystems (Table 8). Cropland contributes the most to the conterminous United States carbon sink with the highest GPP, NPP and NEP. Forests follow cropland to have high total GPP, NPP and contribute about one-third of the total net carbon uptake. With the second largest area, grasslands contribute about one-sixth to one-fifth of total annual GPP and NPP, and one-sixth of total annul NEP. Shrubland has the lowest total annual GPP, NPP while savannas have the lowest total annual NEP. On a per-unit area basis, forests have the highest GPP, follow- ing with cropland and savannas. Deciduous forests have the highest NPP intensity while shrubland and grasslands have the lowest. Deciduous forest NEP is the highest and shrubland have the lowest carbon sink. Overall, deciduous forests and croplands are the main contributors to the national carbon sink over the period 2000-2005.

Since the disturbance damages to vegetation can be reflected by the variations of EVI, use of EVI in TEM helps capture the effects of disturbances on carbon dynamics. For example, the Hurricane Katrina occurred in late August 2005 and affected five million acres of forest across Mississippi, Louisiana and Alabama with downed trees, snapped trunks and broken limbs to stripped leave. Dramatic changes of EVI occurred in the following two months (September and October) after the hurricane in that region. For the most influenced region between $90^{\circ} \mathrm{W} \sim 88^{\circ} \mathrm{W}$ and $29^{\circ} \mathrm{N} \sim 31^{\circ} \mathrm{N}$, the EVI is averagely about 0.04 lower than normal values for each pixel during those two months. SAT-TEM indeed estimated a large negative GPP anomaly in that period (Fig. 8). GPP is $14 \mathrm{~g} \mathrm{C} \mathrm{m}^{-2}$ month $^{-1}$ lower than normal values for each pixel. In contrast, TEM failed to capture these anomalies and even presented positive anomalies due to the 


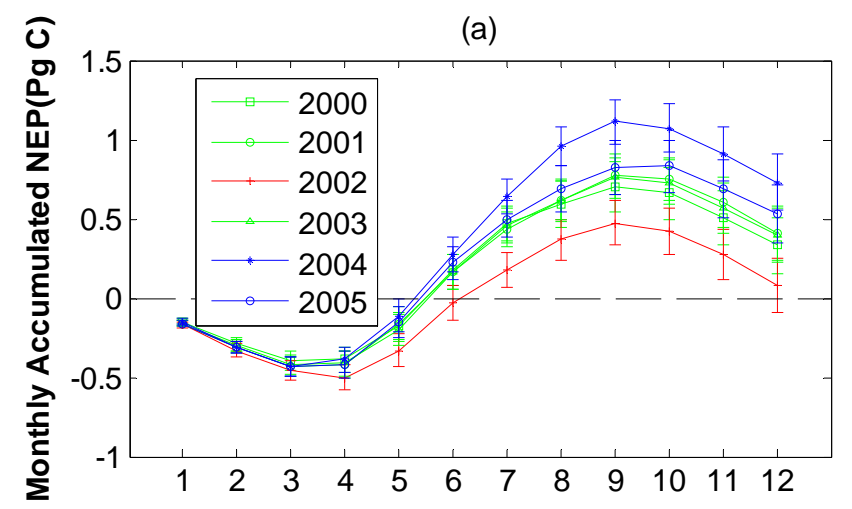

(b)

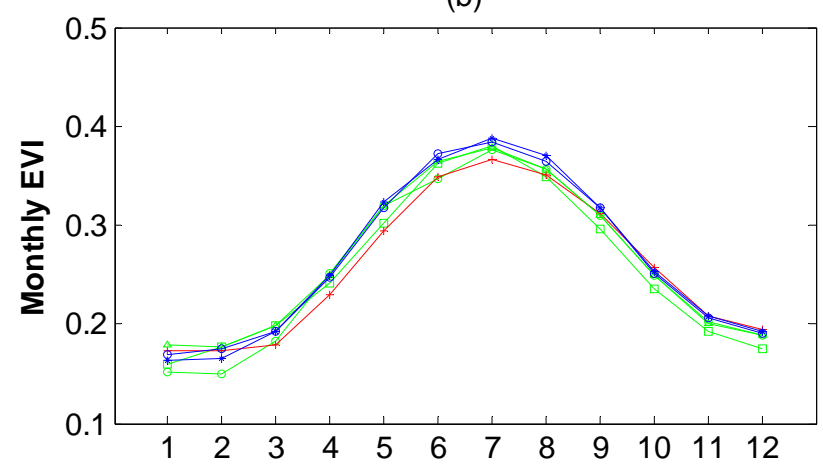

(c)

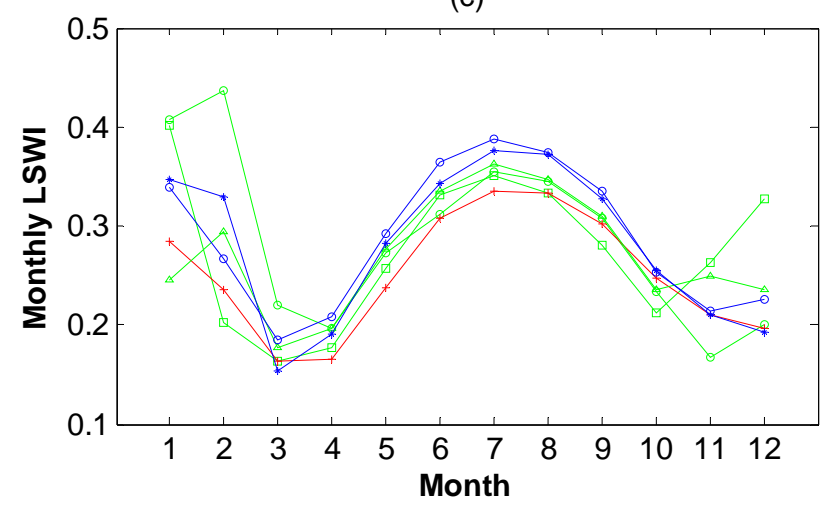

Fig. 6. Comparison between NEP, EVI, and LSWI across the conterminous United States over the period of 2000-2005: (a) Cumulative monthly NEP estimated by SAT-TEM. (b) Monthly averaged regional EVI. (c) Monthly averaged regional LSWI.

abundant water storage in that period. Our SAT-TEM results agree with the findings suggesting Hurricane Katrina had large impacts on the regional carbon budget based on satellite data and empirical approaches (Chambers et al., 2007; Xiao et al., 2010).

\subsection{Possible uncertainties}

The data used to drive SAT-TEM and the parameterization both result in uncertainties to our estimation. As indicated by Zhao et al. (2006), the NCEP reanalysis data overestimated solar radiation and underestimated temperature. The errors in temperature may introduce errors in carbon fluxes because of the nonlinear relationship between temperature and plant maintenance respiration. The heterogeneity of land covers is another important source of uncertainty when we scale the site-level parameterization to the region. For example, $\mathrm{C}_{3}$ and $\mathrm{C}_{4}$ plants in the regional simulations are not treated differently since there is no transient spatially-explicit $\mathrm{C}_{3}$ and $\mathrm{C}_{4}$ plant distribution data.

Second, carbon dynamics are uncertain due to lacking spatially-explicit forest stand age data. In this study, we assume that all ecosystems (e.g. forests) are mature. Parameters generated at the chosen matured forest at Howland and Harvard forest sites do not work for young forests. Thus models may underestimate NPP of the forest in the conterminous United States because the forest productivity generally decreases with stand age (McMurtrie et al., 1995). Although the usage of MODIS vegetation indices can represent some information of the forest age (Waring et al., 2006), more adequate quantification of the regional carbon fluxes should use spatially-explicit data of forest stand age.

Third, the uncertainty came from a limited number of quality ecosystem sites. For example, there are only a few shrubland sites with sufficient observations. The weak constraint on parameters of SAT-TEM for shrubland may bias the results. In addition, more sites in the western US should be established. The significant uncertainties of eddy flux data (Richardson et al., 2008) and the uncertainties introduced by the gap-filling techniques (Moffat et al., 2007) may also bias parameterization and regional results.

Finally, the parameterization could also introduce uncertainty to flux estimates. Here we use the 50 ensemble regional simulations to quantify the errors from parameterization. Parameterizations of different vegetation types contribute differently to the total uncertainties (Fig. 7). The spatial distribution of the relative standard deviation, as the ratio of standard deviation to the mean value indicates that shrubland has the biggest uncertainties. Evergreen forests in the Rocky Mountain area and the upper Midwest are the second largest uncertainty contributor. With the Bayesian Inference method (Tang and Zhuang, 2008, 2009), the possible parameter sets introduce $0.34,0.65$ and $0.18 \mathrm{Pg} \mathrm{C}$ biases to the estimation of the annual GPP, NPP and NEP of the conterminous United States, respectively (Table 6). 

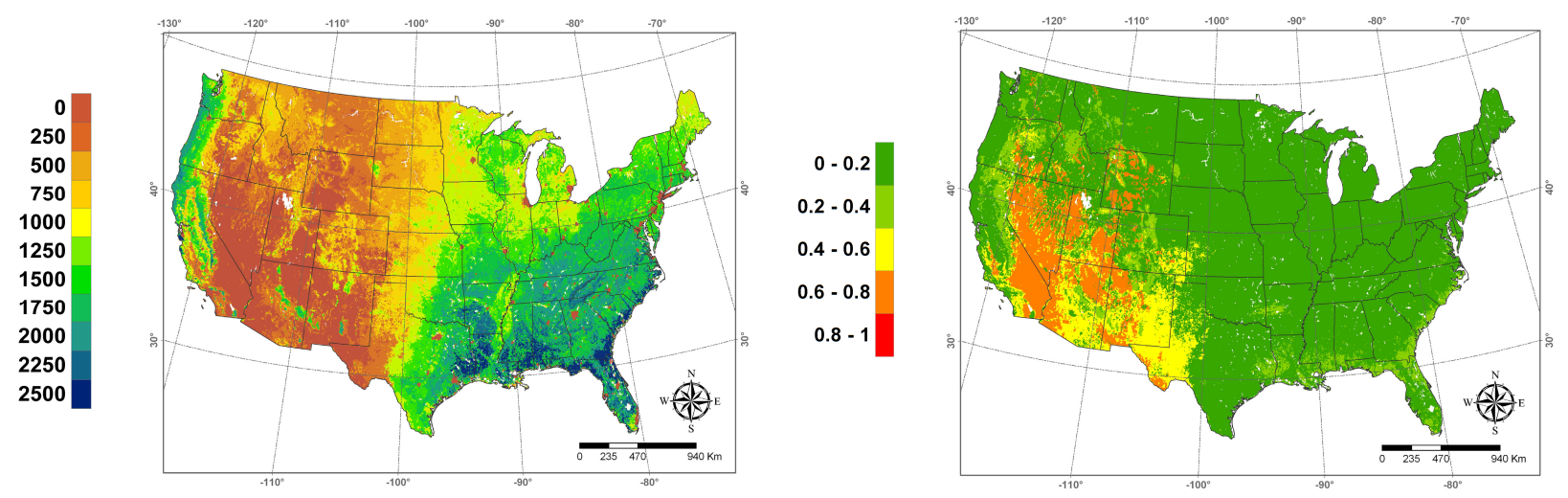

(a) GPP
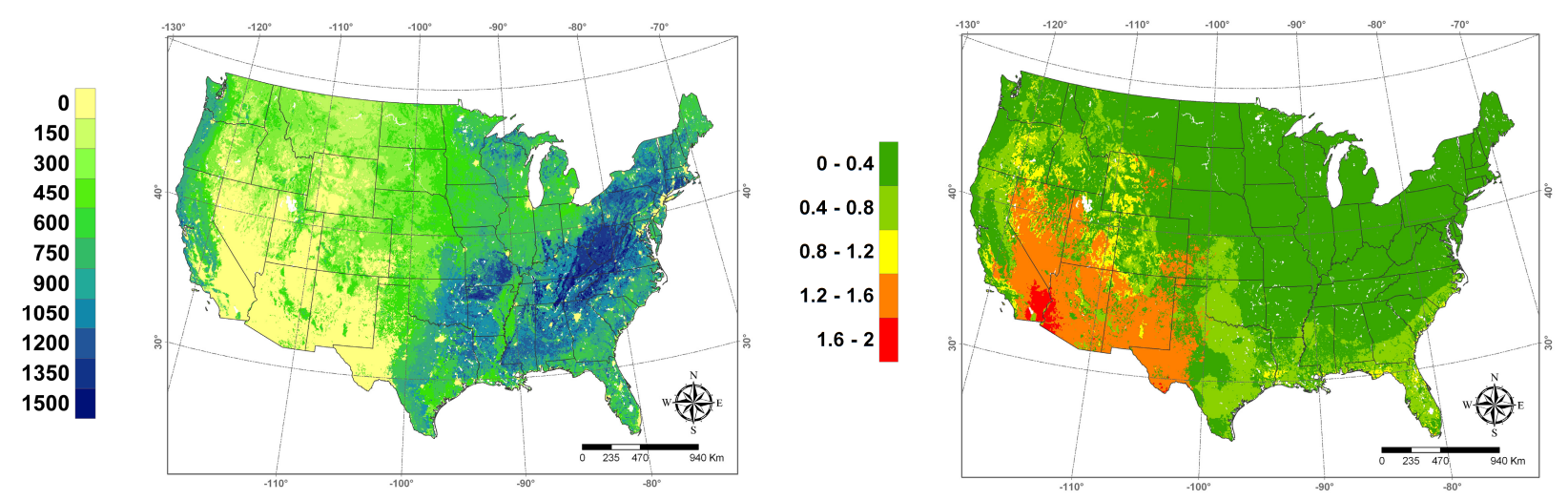

(b) NPP
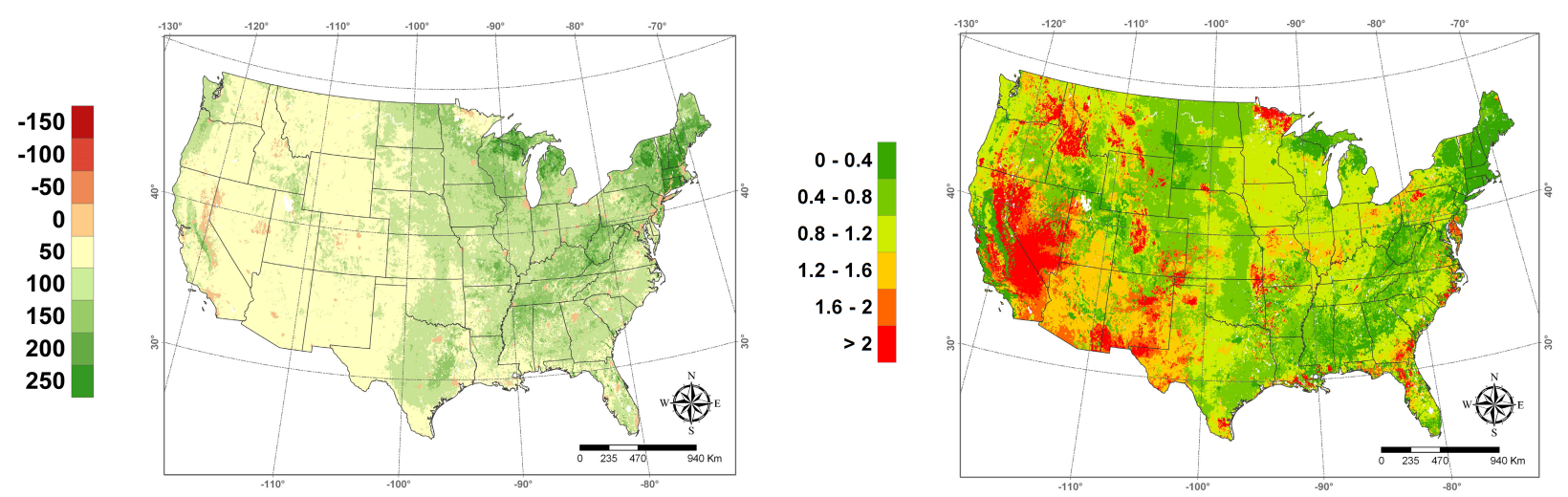

(c) NEP

Fig. 7. Average annual carbon fluxes $\left(\mathrm{g} \mathrm{C} \mathrm{m}^{-2} \mathrm{yr}^{-1}\right)$ (left) and the relative standard deviations (right) of the conterminous United States over the period 2000-2005: (a) GPP; (b) NPP; (c) NEP. The relative standard deviations are calculated by dividing standard deviations by the average values of the regional results of the 50 sets of simulations.

\section{Conclusions}

We incorporate MODIS EVI and LSWI into a process-based biogeochemistry model TEM to more adequately quantify ecosystem carbon dynamics from 2000 to 2005 for the conterminous United States. Multiple eddy flux tower data are used to parameterize and verify the SAT-TEM. Ensemble simulations with the posterior parameters are applied at both site and regional levels. The site-level comparisons indicate that the SAT-TEM performs better. The regional extrapolation of SAT-TEM across the conterminous United States generally captures the expected spatial and temporal carbon dynamics. With SAT-TEM, we estimate that the GPP is between 7.02 and $7.78 \mathrm{PgC} \mathrm{yr}^{-1}$, NPP varies from 3.81 to 
Table 8. TEM estimated annual carbon fluxes for each vegetation type in the conterminous United States during 2000-2005.

\begin{tabular}{|c|c|c|c|c|c|c|c|}
\hline Vegetation Type & 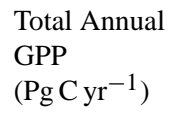 & 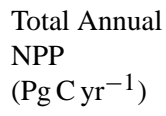 & 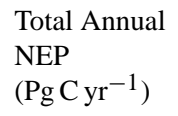 & $\begin{array}{l}\text { Mean Annual } \\
\text { GPP } \\
\left(\mathrm{kg} \mathrm{Cm}^{-2} \mathrm{yr}^{-1}\right)\end{array}$ & $\begin{array}{l}\text { Mean Annual } \\
\text { NPP } \\
\mathrm{kg} \mathrm{Cm}^{-2} \mathrm{yr}^{-1}\end{array}$ & $\begin{array}{l}\text { Mean Annual } \\
\text { NEP } \\
\mathrm{kgCm}^{-2} \mathrm{yr}^{-1}\end{array}$ & $\begin{array}{l}\text { Land Area } \\
\left(\mathrm{km}^{2}\right)\end{array}$ \\
\hline Evergreen Forest & 1.50 & 0.57 & 0.038 & 1.46 & 0.55 & 0.037 & 1028790 \\
\hline Deciduous Forest & 1.28 & 0.95 & 0.110 & 1.53 & 1.13 & 0.131 & 838203 \\
\hline Grassland & 1.31 & 0.83 & 0.075 & 0.75 & 0.48 & 0.043 & 1745960 \\
\hline Shrubland & 0.25 & 0.08 & 0.015 & 0.18 & 0.06 & 0.011 & 1355240 \\
\hline Savannas & 0.39 & 0.27 & 0.012 & 1.34 & 0.93 & 0.041 & 290155 \\
\hline
\end{tabular}

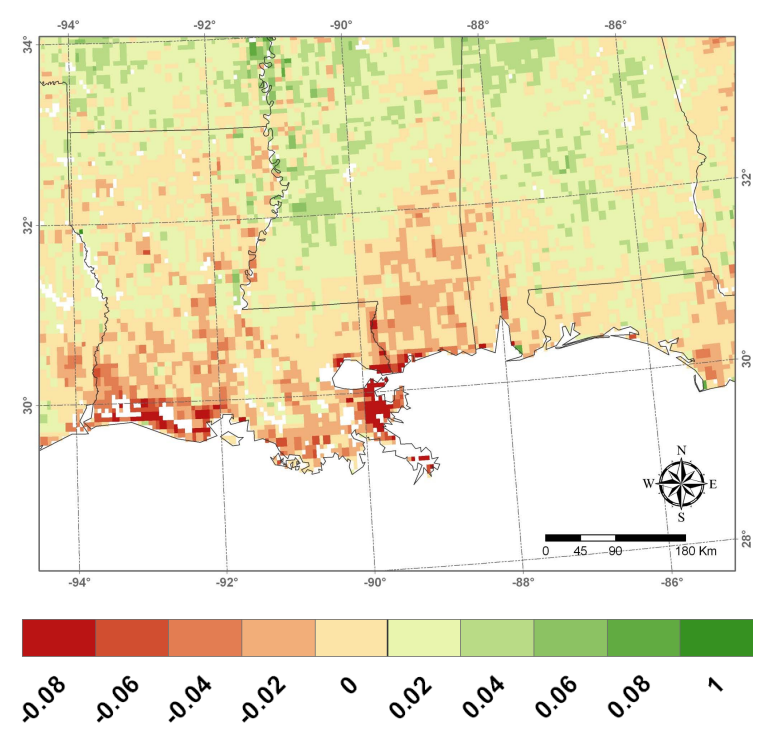

(a) EVI anomalies
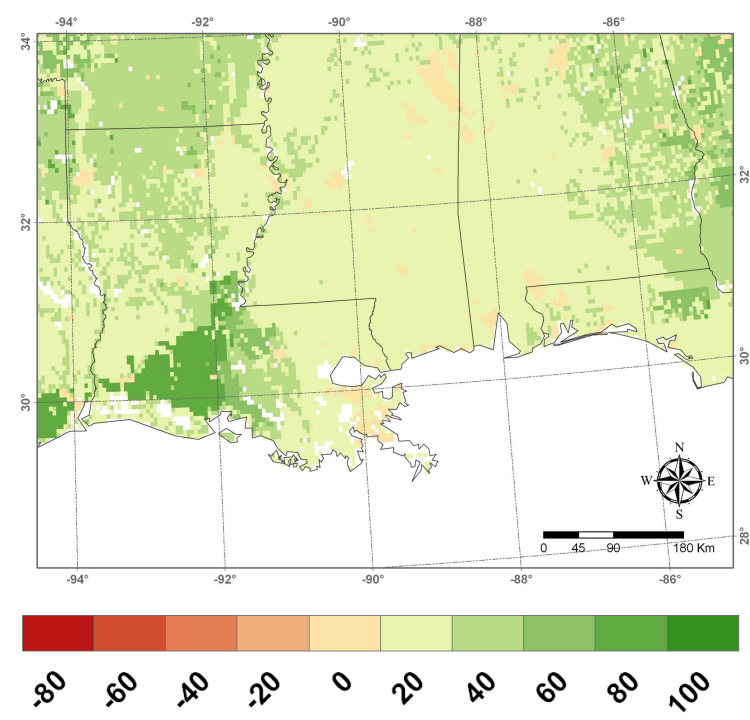

(c) TEM estimated GPP anormalies

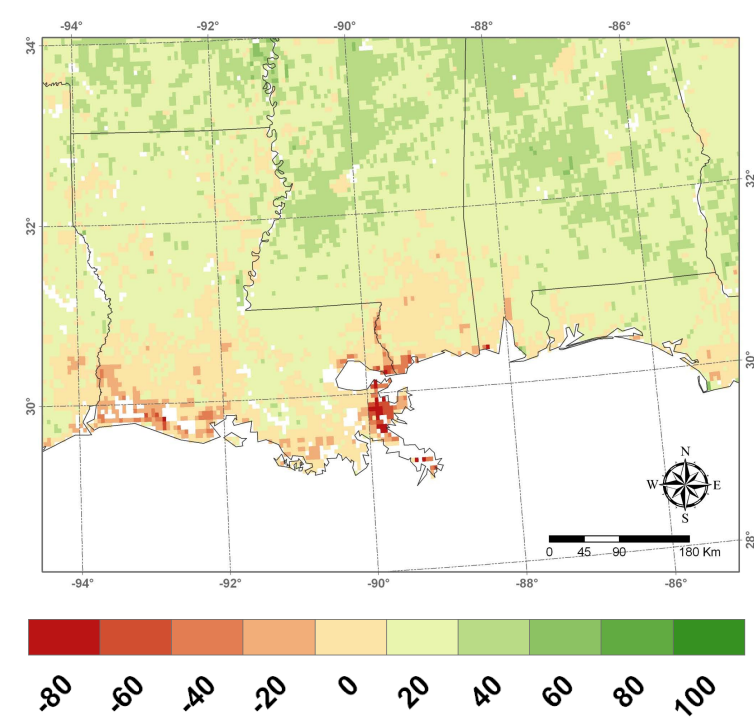

(b) SAT-TEM estimated GPP anomalies

Fig. 8. Impacts of Hurricane Katrina on two-month-average EVI and estimated GPP. Units for GPP are $\mathrm{g} \mathrm{C} \mathrm{m}^{-2} \mathrm{month}^{-1}$. 
4.38 $\mathrm{Pg} \mathrm{C} \mathrm{yr}^{-1}$ and NEP ranges from 0.08 to $0.73 \mathrm{Pg} \mathrm{C} \mathrm{yr}^{-1}$ in the region during the period 2000-2005. The parameterization introduces $0.34,0.65$ and $0.18 \mathrm{Pg} \mathrm{C} \mathrm{yr}^{-1}$ errors to the regional GPP, NPP and NEP, respectively. The effects of extreme climate and disturbances such as severe drought in 2002 and Hurricane Katrina in 2005 are captured in our regional simulations. This study takes advantage of process-based ecosystem modeling, satellite observations and eddy flux tower carbon flux data to provide a more adequate quantification of carbon fluxes for the conterminous United States. Our findings and carbon flux product should benefit studies of carbon-climate feedbacks and facilitate policy-making of carbon management and climate change.

Acknowledgements. We acknowledge the AmeriFlux community to provide the eddy flux data and the MODIS research community to provide MODIS data on vegetation. This research is supported by NSF through projects of ARC-0554811 and EAR-0630319 and the Department of Energy. The study is also supported by NASA land-use and land-cover change program. Computing support is provided by the Rosen Center for Advanced Computing at Purdue University.

Edited by: U. Seibt

\section{References}

Aalto, T., Ciais, P., Chevillard, A., and Moulin, C.: Optimal determination of the parameters controlling biospheric $\mathrm{CO}_{2}$ fluxes over Europe using eddy covariance fluxes and satellite NDVI measurements, Tellus B, 56, 93-104, 2004.

AmeriFlux Network, published at: http://ameriflux.ornl.gov/, 2009.

Baldocchi, D., Falge, E., Gu, L., Olson, R., Hollinger, D., Running, S., Anthoni, P., Bernhofer, C., Davis, K., Evans, R., Fuentes, J., Goldstein, A., Katul, G., Law, B., Lee, X., Malhi, Y., Meyers, T., Munger, W., Oechel, W., Paw, K. T., Pilegaard, K., Schmid, H. P., Valentini, R., Verma, S., Vesala, T., Wilson, K., and Wofsy, S.: FLUXNET: A New Tool to Study the Temporal and Spatial Variability of EcosystemScale Carbon Dioxide, Water Vapor, and Energy Flux Densities, B. Am. Meteorol. Soc., 82, 2415-2434, doi:10.1175/15200477(2001)082<2415:FANTTS>2.3.CO;2, 2001.

Boles, S. H., Xiao, X., Liu, J., Zhang, Q., Munkhtuya, S., Chen, S., and Ojima, D.: Land cover characterization of Temperate East Asia using multi-temporal VEGETATION sensor data, Remote Sens. Environ., 90, 477-489, 2004.

Braswell, B. H., Sacks, W. J., Linder, E., and Schimel, D. S.: Estimating diurnal to annual ecosystem parameters by synthesis of a carbon flux model with eddy covariance net ecosystem exchange observations, Glob. Change Biol., 11, 335-355, 2005.

Canadell, J. G., Mooney, H. A., Baldocchi, D. D., Berry, J. A., Ehleringer, J. R., Field, C. B., Gower, S. T., Hollinger, D. Y., Hunt, J. E., Jackson, R. B., Running, S. W., Shaver, G. R., Steffen, W., Trumbor, S. E., Valentini, R., and Bond, B. Y.: Carbon metabolism of the terrestrial biosphere: A multitechnique approach for improved understanding, 2, Springer, New York, NY, ETATS-UNIS, 2000.
Chambers, J. Q., Fisher, J. I., Zeng, H., Chapman, E. L., Baker, D. B., and Hurtt, G. C.: Hurricane Katrina's Carbon Footprint on U.S. Gulf Coast Forests, Science, 318, 1107, doi:10.1126/science.1148913, 2007.

Clark, K. L., Gholz, H. L., Moncrieff, J. B., Cropley, F., and Loescher, H. W.: Environmental Controls over Net Exchanges of Carbon Dioxide from Contrasting Florida Ecosystems, Ecol. Appl., 9, 936-948, 1999.

Clark, K. L., Gholz, H. L., and Castro, M. S.: Carbon dynamics along a chronosequence of slash pine plantations in north florida, Ecol. Appl., 14, 1154-1171, doi:10.1890/02-5391, 2004.

Cook, B. D., Davis, K. J., Wang, W., Desai, A., Berger, B. W., Teclaw, R. M., Martin, J. G., Bolstad, P. V., Bakwin, P. S., Yi, C., and Heilman, W.: Carbon exchange and venting anomalies in an upland deciduous forest in northern Wisconsin, USA, Agr. Forest Meteorol., 126, 271-295, 2004.

Coops, N. C., Waring, R. H., and Landsberg, J. J.: Assessing forest productivity in Australia and New Zealand using a physiologically-based model driven with averaged monthly weather data and satellite-derived estimates of canopy photosynthetic capacity, Forest Ecol. Manage., 104, 113-127, 1998.

Coulter, R. L., Pekour, M. S., Cook, D. R., Klazura, G. E., Martin, T. J., and Lucas, J. D.: Surface energy and carbon dioxide fluxes above different vegetation types within ABLE, Agr. Forest Meteorol., 136, 147-158, 2006.

Deng, F., Chen, J. M., Ishizawa, M., Yuen, C.-W., Mo, G., Higuchi, K., Chan, D., and Maksyutov, S.: Global monthly $\mathrm{CO}_{2}$ flux inversion with a focus over North America, Tellus B, 59, 179-190, 2007.

Falk, M., Wharton, S., Schroeder, M., Ustin, S., and U, K. T. P.: Flux partitioning in an old-growth forest: seasonal and interannual dynamics, Tree Physiol., 28, 509-520, 2008.

Fan, S., Gloor, M., Mahlman, J., Pacala, S., Sarmiento, J., Takahashi, T., and Tans, P.: A Large Terrestrial Carbon Sink in North America Implied by Atmospheric and Oceanic Carbon Dioxide Data and Models, Science, 282, 442-446, doi:10.1126/science.282.5388.442, 1998.

Field, C. B., Randerson, J. T., and Malmström, C. M.: Global net primary production: Combining ecology and remote sensing, Remote Sens. Environ., 51, 74-88, 1995.

Goward, S. N. and Huemmrich, K. F.: Vegetation canopy PAR absorptance and the normalized difference vegetation index: An assessment using the SAIL model, Remote Sens. Environ., 39, 119-140, 1992.

Green, E. J., MacFarlane, D. W., Valentine, H. T., and Strawderman, W. E.: Assessing Uncertainty in a Stand Growth Model by Bayesian Synthesis, Forest Sci., 45, 528-538, 1999.

Griffis, T. J., Sargent, S. D., Baker, J. M., Lee, X., Tanner, B. D., Greene, J., Swiatek, E., and Billmark, K.: Direct measurement of biosphere-atmosphere isotopic $\mathrm{CO}_{2}$ exchange using the eddy covariance technique, J. Geophys. Res., 113, D08304, doi:10.1029/2007jd009297, 2008.

Guenther, B., Xiong, X., Salomonson, V. V., Barnes, W. L., and Young, J.: On-orbit performance of the Earth Observing System Moderate Resolution Imaging Spectroradiometer; first year of data, Remote Sens. Environ., 83, 16-30, 2002.

Gurney, K. R., Law, R. M., Denning, A. S., Rayner, P. J., Baker, D., Bousquet, P., Bruhwiler, L., Chen, Y.-H., Ciais, P., Fan, S., Fung, I. Y., Gloor, M., Heimann, M., Higuchi, K., John, J., Maki, 
T., Maksyutov, S., Masarie, K., Peylin, P., Prather, M., Pak, B. C., Randerson, J., Sarmiento, J., Taguchi, S., Takahashi, T., and Yuen, C.-W.: Towards robust regional estimates of $\mathrm{CO}_{2}$ sources and sinks using atmospheric transport models, Nature, 415, 626630, 2002.

Hazarika, M. K., Yasuoka, Y., Ito, A., and Dye, D.: Estimation of net primary productivity by integrating remote sensing data with an ecosystem model, Remote Sens. Environ., 94, 298-310, 2005.

Hollinger, D. Y., Goltz, S. M., Davidson, E. A., Lee, J. T., Tu, K., and Valentine, H. T.: Seasonal patterns and environmental control of carbon dioxide and water vapour exchange in an ecotonal boreal forest, Glob. Change Biol., 5, 891-902, 1999.

Hollinger, D. Y., Aber, J., Dail, B., Davidson, E. A., Goltz, S. M., Hughes, H., Leclerc, M. Y., Lee, J. T., Richardson, A. D., Rodrigues, C., Scott, N. A., Achuatavarier, D., and Walsh, J.: Spatial and temporal variability in forest-atmosphere $\mathrm{CO}_{2}$ exchange, Glob. Change Biol., 10, 1689-1706, 2004.

Hollinger, S. E., Bernacchi, C. J., and Meyers, T. P.: Carbon budget of mature no-till ecosystem in North Central Region of the United States, Agr. Forest Meteorol., 130, 59-69, 2005.

Houghton, R. A. and Hackler, J. L.: Changes in Terrestrial Carbon Storage in the United States. 1: The Roles of Agriculture and Forestry, Global Ecol. Biogeogr., 9, 125-144, 2000

Houghton, R. A., Hackler, J. L., and Lawrence, K. T.: The U.S. Carbon Budget: Contributions from Land-Use Change, Science, 285, 574-578, doi:10.1126/science.285.5427.574, 1999.

Houghton, R. A., Hackler, J. L., and Lawrence, K. T.: Changes in Terrestrial Carbon Storage in the United States. 2: The Role of Fire and Fire Management, Global Ecol. Biogeogr., 9, 145-170, 2000.

Huete, A., Liu, H. Q., Batchily, K., and van Leeuwen, W.: A comparison of vegetation indices over a global set of TM images for EOS-MODIS, Remote Sens. Environ., 59, 440-451, 1997.

Huete, A., Didan, K., Miura, T., Rodriguez, E. P., Gao, X., and Ferreira, L. G.: Overview of the radiometric and biophysical performance of the MODIS vegetation indices, Remote Sens. Environ., 83, 195-213, 2002.

Iman, R. L. and Helton, J. C.: An Investigation of Uncertainty and Sensitivity Analysis Techniques for Computer Models, Risk Anal., 8, 71-90, 1988.

IPCC: Climate Change 2001: Synthesis Report. A Contribution of Working Groups I, II, and III to the Third Assessment Report of the Intergovernmental Panel on Climate Change, edited by: Watson, R. T. and the Core Writing Team, Cambridge University Press, Cambridge, United Kingdom and New York, NY, 2001.

Justice, C. O., Townshend, J. R. G., Vermote, E. F., Masuoka, E., Wolfe, R. E., Saleous, N., Roy, D. P., and Morisette, J. T.: An overview of MODIS Land data processing and product status, Remote Sens. Environ., 83, 3-15, 2002.

Kistler, R., Collins, W., Saha, S., White, G., Woollen, J., Kalnay, E., Chelliah, M., Ebisuzaki, W., Kanamitsu, M., Kousky, V., van den Dool, H., Jenne, R., and Fiorino, M.: The NCEP-NCAR 50-Year Reanalysis: Monthly Means CD-ROM and Documentation, B. Am. Meteorol. Soc., 82, 247-267, doi:10.1175/15200477(2001)082<0247:TNNYRM>2.3.CO;2, 2001.

Law, B., Turner, D., Campbell, J., Lefsky, M., Guzy, M., Sun, O., Tuyl, S., and Cohen, W.: Carbon fluxes across regions: observational constraints at multiple scales, in: Scaling and Uncertainty Analysis in Ecology: Methods and Applications, edited by: Wu,
J., Jones, K. B., Li, H., and Loucks, O. L., Columbia University Press, New York, 167-190, 2006.

Li, Z., Yu, G., Xiao, X., Li, Y., Zhao, X., Ren, C., Zhang, L., and $\mathrm{Fu}$, Y.: Modeling gross primary production of alpine ecosystems in the Tibetan Plateau using MODIS images and climate data, Remote Sens. Environ., 107, 510-519, 2007.

Lipson, D. A., Wilson, R. F., and Oechel, W. C.: Effects of Elevated Atmospheric $\mathrm{CO}_{2}$ on Soil Microbial Biomass, Activity, and Diversity in a Chaparral Ecosystem, Appl. Environ. Microbiol., 71, 8573-8580, doi:10.1128/aem.71.12.8573-8580.2005, 2005.

$\mathrm{Lu}, \mathrm{X}$. and Zhuang, Q.: Evaluating climate impacts on carbon balance of the terrestrial ecosystems in the Midwest of the United States with a process-based ecosystem model, Mitigation and Adaptation Strategies for Global Change, 15, 467-487, 2010.

Ma, S., Baldocchi, D. D., Xu, L., and Hehn, T.: Inter-annual variability in carbon dioxide exchange of an oak/grass savanna and open grassland in California, Agr. Forest Meteorol., 147, 157$171,2007$.

McGuire, A. D., Melillo, J. M., Joyce, L. A., Kicklighter, D. W., Grace, A. L., Moore III, B., and Vorosmarty, C. J.: Interactions Between Carbon and Nitrogen Dynamics in Estimating Net Primary Productivity For Potential Vegetation in North America, Global Biogeochem. Cy., 6, 101-124, doi:10.1029/92gb00219, 1992.

McGuire, A. D., Sitch, S., Clein, J. S., Dargaville, R., Esser, G., Foley, J., Heimann, M., Joos, F., Kaplan, J., Kicklighter, D. W., Meier, R. A., Melillo, J. M., Moore III, B., Prentice, I. C., Ramankutty, N., Reichenau, T., Schloss, A., Tian, H., Williams, L. J., and Wittenberg, U.: Carbon Balance of the Terrestrial Biosphere in the Twentieth Century: Analyses of $\mathrm{CO}_{2}$, Climate and Land Use Effects With Four ProcessBased Ecosystem Models, Global Biogeochem. Cy., 15, 183206, doi:10.1029/2000gb001298, 2001.

McMurtrie, R. E., Gower, S. T., and Ryan, M. G.: Forest Productivity: Explaining Its Decline with Stand Age, Bulletin of the Ecological Society of America, 76, 152-154, 1995.

Melillo, J. M., McGuire, A. D., Kicklighter, D. W., Moore, B., Vorosmarty, C. J., and Schloss, A. L.: Global climate change and terrestrial net primary production, Nature, 363, 234-240, 1993.

Moffat, A. M., Papale, D., Reichstein, M., Hollinger, D. Y., Richardson, A. D., Barr, A. G., Beckstein, C., Braswell, B. H., Churkina, G., Desai, A. R., Falge, E., Gove, J. H., Heimann, M., Hui, D., Jarvis, A. J., Kattge, J., Noormets, A., and Stauch, V. J.: Comprehensive comparison of gap-filling techniques for eddy covariance net carbon fluxes, Agr. Forest Meteorol., 147, 209-232, 2007.

Monson, R. K., Turnipseed, A. A., Sparks, J. P., Harley, P. C., ScottDenton, L. E., Sparks, K., and Huxman, T. E.: Carbon sequestration in a high-elevation, subalpine forest, Glob. Change Biol., 8, 459-478, 2002.

Myneni, R. B., Hoffman, S., Knyazikhin, Y., Privette, J. L., Glassy, J., Tian, Y., Wang, Y., Song, X., Zhang, Y., Smith, G. R., Lotsch, A., Friedl, M., Morisette, J. T., Votava, P., Nemani, R. R., and Running, S. W.: Global products of vegetation leaf area and fraction absorbed PAR from year one of MODIS data, Remote Sens. Environ., 83, 214-231, 2002.

Pacala, S. W., Hurtt, G. C., Baker, D., Peylin, P., Houghton, R. A., Birdsey, R. A., Heath, L., Sundquist, E. T., Stallard, R. F., Ciais, P., Moorcroft, P., Caspersen, J. P., Shevliakova, 
E., Moore, B., Kohlmaier, G., Holland, E., Gloor, M., Harmon, M. E., Fan, S.-M., Sarmiento, J. L., Goodale, C. L., Schimel, D., and Field, C. B.: Consistent Land- and AtmosphereBased U.S. Carbon Sink Estimates, Science, 292, 2316-2320, doi:10.1126/science.1057320, 2001.

Papale, D. and Valentini, R.: A new assessment of European forests carbon exchanges by eddy fluxes and artificial neural network spatialization, Glob. Change Biol., 9, 525-535, 2003.

Pinter, P. J., Jackson, R. D., Idso, S. B., and Reginato, R. J.: Diurnal Patterns of Wheat Spectral Reflectances, IEEE T. Geosci. Remote, GE-21, 156-163, 1983.

Pinter, P. J., Jackson, R. D., Ezra, C. E., and Gausman, H. W.: Sunangle and canopy-architecture effects on the spectral reflectance of six wheat cultivars, Int. J. Remote Sens., 6, 1813-1825, 1985.

Potter, C., Klooster, S., Myneni, R., Genovese, V., Tan, P.-N., and Kumar, V.: Continental-scale comparisons of terrestrial carbon sinks estimated from satellite data and ecosystem modeling 1982-1998, Global Planet. Change, 39, 201-213, 2003.

Potter, C., Klooster, S., Huete, A., and Genovese, V.: Terrestrial Carbon Sinks for the United States Predicted from MODIS Satellite Data and Ecosystem Modeling, Earth Interact., 11, 1-21, doi:10.1175/EI228.1, 2007.

Potter, C. S., Randerson, J. T., Field, C. B., Matson, P. A., Vitousek, P. M., Mooney, H. A., and Klooster, S. A.: Terrestrial Ecosystem Production: a Process Model Based on Global Satellite and Surface Data, Global Biogeochem. Cy., 7, 811-841, doi:10.1029/93gb02725, 1993.

Prince, S. D. and Goward, S. N.: Global primary production: A remote sensing approach, J. Biogeogr., 22, 815-835, 1995.

Rahman, A. F., Sims, D. A., Cordova, V. D., and El-Masri, B. Z.: Potential of MODIS EVI and surface temperature for directly estimating per-pixel ecosystem C fluxes, Geophys. Res. Lett., 32, L19404, doi:10.1029/2005g1024127, 2005.

Raich, J. W., Rastetter, E. B., Melillo, J. M., Kicklighter, D. W., Steudler, P. A., Peterson, B. J., Grace, A. L., Iii, B. M., and Vörösmarty, C. J.: Potential Net Primary Productivity in South America: Application of a Global Model, Ecol. Appl., 1, 399429, 1991.

Ratana, P., Huete, A. R., Yuan, Y., and Jacobson, A.: Interrelationship among among MODIS vegetation products across an Amazon Eco-climatic gradient, Geoscience and Remote Sensing Symposium, 2005. IGARSS '05. Proceedings. 2005 IEEE International, Seoul, Korea, 3009-3012, 25-29 July 2005.

Reichstein, M., Subke, J.-A., Angeli, A. C., and Tenhunen, J. D.: Does the temperature sensitivity of decomposition of soil organic matter depend upon water content, soil horizon, or incubation time?, Glob. Change Biol., 11, 1754-1767, 2005.

Richardson, A. D., Mahecha, M. D., Falge, E., Kattge, J., Moffat, A. M., Papale, D., Reichstein, M., Stauch, V. J., Braswell, B. H., Churkina, G., Kruijt, B., and Hollinger, D. Y.: Statistical properties of random $\mathrm{CO}_{2}$ flux measurement uncertainty inferred from model residuals, Agr. Forest Meteorol., 148, 38-50, 2008.

Running, S., Nemani, R., Heinsch, F., Zhao, M., Reeves, M., and Hashimoto, H.: A continuous satellite-derived measure of global terrestrial primary production, BioScience, 54, 547-560, 2004.

Running, S. W. and Hunt Jr., E. R.: Generalization of a forest ecosystem process model for other biomes, BIOME-BGC, and an application for global-scale models, in: Scaling Physiological Processes: Leaf to Globe, edited by: Field, J. R. E. a. C.,
Academic Press, San Diego, CA, 141-158, 1993.

Running, S. W., Nemani, R., Glassy, J. M., and Thornton, P.: MODIS Daily photosynthesis (PSN) and annual net primary production (NPP) product (MOD17), Algorithm Theoretical Basis Document, Version 3.0, 29 April 1999.

Running, S. W., Thornton, P. E., Nemani, R., and Glassy, J. M.: Global terrestrial gross and net primary productivity from the Earth Observing System, in: Methods in ecosystem science, edited by: Sala, O. E., Jackson, R. B., Mooney, H. A., and Howarth, R. W., New York: Springer, 44-57, 2000.

Santaren, D., Peylin, P., Viovy, N., and Ciais, P.: Optimizing a process-based ecosystem model with eddy-covariance flux measurements: A pine forest in southern France, Global Biogeochem. Cy., 21, GB2013, doi:10.1029/2006gb002834, 2007.

Schimel, D., Melillo, J., Tian, H., McGuire, A. D., Kicklighter, D., Kittel, T., Rosenbloom, N., Running, S., Thornton, P., Ojima, D., Parton, W., Kelly, R., Sykes, M., Neilson, R., and Rizzo, B.: Contribution of Increasing $\mathrm{CO}_{2}$ and Climate to Carbon Storage by Ecosystems in the United States, Science, 287, 2004-2006, doi:10.1126/science.287.5460.2004, 2000.

Schmid, H. P.: Footprint modeling for vegetation atmosphere exchange studies: a review and perspective, Agr. Forest Meteorol., 113, 159-183, 2002.

Schmid, H. P., Grimmond, C. S. B., Cropley, F., Offerle, B., and Su, H.-B.: Measurements of $\mathrm{CO}_{2}$ and energy fluxes over a mixed hardwood forest in the mid-western United States, Agr. Forest Meteorol., 103, 357-374, 2000.

Scott, R. L., Jenerette, G. D., Potts, D. L., and Huxman, T. E.: Effects of seasonal drought on net carbon dioxide exchange from a woody-plant-encroached semiarid grassland, J. Geophys. Res., 114, G04004, , 2009.

Scott, R. L., Hamerlynck, E. P., Jenerette, G. D., Moran, M. S., and Barron-Gafford, G. A.: Carbon dioxide exchange in a semidesert grassland through drought-induced vegetation change, J. Geophys. Res., 115, G03026, doi:10.1029/2010jg001348, 2010.

Seaquist, J. W., Olsson, L., and Ardö, J.: A remote sensing-based primary production model for grassland biomes, Ecol. Modell., 169, 131-155, 2003.

Sims, D. A., Rahman, A. F., Cordova, V. D., El-Masri, B. Z., Baldocchi, D. D., Flanagan, L. B., Goldstein, A. H., Hollinger, D. Y., Misson, L., Monson, R. K., Oechel, W. C., Schmid, H. P., Wofsy, S. C., and Xu, L.: On the use of MODIS EVI to assess gross primary productivity of North American ecosystems, J. Geophys. Res., 111, G04015, doi:10.1029/2006jg000162, 2006.

Sims, D. A., Rahman, A. F., Cordova, V. D., El-Masri, B. Z., Baldocchi, D. D., Bolstad, P. V., Flanagan, L. B., Goldstein, A. H., Hollinger, D. Y., Misson, L., Monson, R. K., Oechel, W. C., Schmid, H. P., Wofsy, S. C., and Xu, L.: A new model of gross primary productivity for North American ecosystems based solely on the enhanced vegetation index and land surface temperature from MODIS, Remote Sens. Environ., 112, 1633-1646, 2008.

Skare, Ø., Bølviken, E., and Holden, L.: Improved SamplingImportance Resampling and Reduced Bias Importance Sampling, Scand. J. Stat., 30, 719-737, 2003.

Suyker, A. E., Verma, S. B., Burba, G. G., and Arkebauer, T. J.: Gross primary production and ecosystem respiration of irrigated maize and irrigated soybean during a growing season, Agr. Forest Meteorol., 131, 180-190, 2005. 
Tang, J. and Zhuang, Q.: Equifinality in parameterization of process-based biogeochemistry models: A significant uncertainty source to the estimation of regional carbon dynamics, J. Geophys. Res., 113, G04010, doi:10.1029/2008jg000757, 2008.

Tang, J. and Zhuang, Q.: A global sensitivity analysis and Bayesian inference framework for improving the parameter estimation and prediction of a process-based Terrestrial Ecosystem Model, J. Geophys. Res., 114, D15303, doi:10.1029/2009jd011724, 2009.

Turner, D. P., Koerper, G. J., Harmon, M. E., and Lee, J. J.: A Carbon Budget for Forests of the Conterminous United States, Ecol. Appl., 5, 421-436, doi:10.2307/1942033, 1995.

Urbanski, S., Barford, C., Wofsy, S., Kucharik, C., Pyle, E., Budney, J., McKain, K., Fitzjarrald, D., Czikowsky, M., and Munger, J. W.: Factors controlling $\mathrm{CO}_{2}$ exchange on timescales from hourly to decadal at Harvard Forest, J. Geophys. Res., 112, G02020, doi:10.1029/2006jg000293, 2007.

Wang, Y.-P., Leuning, R., Cleugh, H. A., and Coppin, P. A.: Parameter estimation in surface exchange models using nonlinear inversion: how many parameters can we estimate and which measurements are most useful?, Glob. Change Biol., 7, 495-510, 2001.

Wang, Y.-P., Baldocchi, D., Leuning, R., Falge, E., and Vesala, T.: Estimating parameters in a land-surface model by applying nonlinear inversion to eddy covariance flux measurements from eight FLUXNET sites, Glob. Change Biol., 13, 652-670, 2007.

Waring, R. H., Milner, K. S., Jolly, W. M., Phillips, L., and McWethy, D.: Assessment of site index and forest growth capacity across the Pacific and Inland Northwest U.S.A. with a MODIS satellite-derived vegetation index, Forest Ecol. Manage., 228, 285-291, 2006.

Williams, M., Schwarz, P. A., Law, B. E., Irvine, J., and Kurpius, M. R.: An improved analysis of forest carbon dynamics using data assimilation, Glob. Change Biol., 11, 89-105, 2005.

Wofsy, S. C., Goulden, M. L., Munger, J. W., Fan, S.-M., Bakwin, P. S., Daube, B. C., Bassow, S. L., and Bazzaz, F. A.: Net Exchange of $\mathrm{CO}_{2}$ in a Mid-Latitude Forest, Science, 260, 13141317, doi:10.1126/science.260.5112.1314, 1993.

Wolfe, R. E., Nishihama, M., Fleig, A. J., Kuyper, J. A., Roy, D. P., Storey, J. C., and Patt, F. S.: Achieving sub-pixel geolocation accuracy in support of MODIS land science, Remote Sens. Environ., 83, 31-49, 2002.

Xiao, J., Zhuang, Q., Baldocchi, D. D., Law, B. E., Richardson, A. D., Chen, J., Oren, R., Starr, G., Noormets, A., Ma, S., Verma, S. B., Wharton, S., Wofsy, S. C., Bolstad, P. V., Burns, S. P., Cook, D. R., Curtis, P. S., Drake, B. G., Falk, M., Fischer, M. L., Foster, D. R., Gu, L., Hadley, J. L., Hollinger, D. Y., Katul, G. G., Litvak, M., Martin, T. A., Matamala, R., McNulty, S., Meyers, T. P., Monson, R. K., Munger, J. W., Oechel, W. C., Paw U, K. T., Schmid, H. P., Scott, R. L., Sun, G., Suyker, A. E., and Torn, M. S.: Estimation of net ecosystem carbon exchange for the conterminous United States by combining MODIS and AmeriFlux data, Agr. Forest Meteorol., 148, 1827-1847, 2008.

Xiao, J., Zhuang, Q., Law, B. E., Chen, J., Baldocchi, D. D., Cook, D. R., Oren, R., Richardson, A. D., Wharton, S., Ma, S., Martin, T. A., Verma, S. B., Suyker, A. E., Scott, R. L., Monson, R. K., Litvak, M., Hollinger, D. Y., Sun, G., Davis, K. J., Bolstad, P. V., Burns, S. P., Curtis, P. S., Drake, B. G., Falk, M., Fischer, M. L., Foster, D. R., Gu, L., Hadley, J. L., Katul, G. G., Matamala, R., McNulty, S., Meyers, T. P., Munger, J. W., Noormets, A., Oechel, W. C., Paw U, K. T., Schmid, H. P., Starr,
G., Torn, M. S., and Wofsy, S. C.: A continuous measure of gross primary production for the conterminous United States derived from MODIS and AmeriFlux data, Remote Sens. Environ., 114, 576-591, 2010.

Xiao, J., Zhuang, Q., Law, B. E., Baldocchi, D. D., Chen, J., Richardson, A. D., Melillo, J. M., Davis, K. J., Hollinger, D. Y., Wharton, S., Oren, R., Noormets, A., Fischer, M. L., Verma, S. B., Cook, D. R., Sun, G., McNulty, S., Wofsy, S. C., Bolstad, P. V., Burns, S. P., Curtis, P. S., Drake, B. G., Falk, M., Foster, D. R., Gu, L., Hadley, J. L., Katul, G. G., Litvak, M., Ma, S., Martin, T. A., Matamala, R., Meyers, T. P., Monson, R. K., Munger, J. W., Oechel, W. C., Paw, U. K. T., Schmid, H. P., Scott, R. L., Starr, G., Suyker, A. E., and Torn, M. S.: Assessing net ecosystem carbon exchange of U.S. terrestrial ecosystems by integrating eddy covariance flux measurements and satellite observations, Agr. Forest Meteorol., 151, 60-69, 2011.

Xiao, X., Hollinger, D., Aber, J., Goltz, M., Davidson, E. A., Zhang, Q., and Moore, B.: Satellite-based modeling of gross primary production in an evergreen needleleaf forest, Remote Sens. Environ., 89, 519-534, 2004.

$\mathrm{Xu}, \mathrm{L}$. and Baldocchi, D. D.: Seasonal variation in carbon dioxide exchange over a Mediterranean annual grassland in California, Agr. Forest Meteorol., 123, 79-96, 2004.

Yan, H., Fu, Y., Xiao, X., Huang, H. Q., He, H., and Ediger, L.: Modeling gross primary productivity for winter wheat-maize double cropping system using MODIS time series and $\mathrm{CO}_{2}$ eddy flux tower data, Agr. Ecosyst. Environ., 129, 391-400, 2009.

Yang, F., Ichii, K., White, M. A., Hashimoto, H., Michaelis, A. R., Votava, P., Zhu, A. X., Huete, A., Running, S. W., and Nemani, R. R.: Developing a continental-scale measure of gross primary production by combining MODIS and AmeriFlux data through Support Vector Machine approach, Remote Sens. Environ., 110, 109-122, 2007.

Zhao, M. and Running, S. W.: Remote Sensing of Terrestrial Primary Production and Carbon Cycle, in: Advances in Land Remote Sensing, edited by: Liang, S., Springer Netherlands, 423 444, 2008.

Zhao, M., Heinsch, F. A., Nemani, R. R., and Running, S. W.: Improvements of the MODIS terrestrial gross and net primary production global data set, Remote Sens. Environ., 95, 164-176, 2005.

Zhao, M., Running, S. W., and Nemani, R. R.: Sensitivity of Moderate Resolution Imaging Spectroradiometer (MODIS) terrestrial primary production to the accuracy of meteorological reanalyses, J. Geophys. Res., 111, G01002, doi:10.1029/2004jg000004, 2006.

Zhuang, Q., Romanovsky, V. E., and McGuire, A. D.: Incorporation of a permafrost model into a large-scale ecosystem model: Evaluation of temporal and spatial scaling issues in simulating soil thermal dynamics, J. Geophys. Res., 106, D24, doi:10.1029/2001jd900151, 2001.

Zhuang, Q., McGuire, A. D., O’Neill, K. P., Harden, J. W., Romanovsky, V. E., and Yarie, J.: Modeling soil thermal and carbon dynamics of a fire chronosequence in interior Alaska, J. Geophys. Res., 107, 8147, doi:10.1029/2001jd001244, 2002.

Zhuang, Q., McGuire, A. D., Melillo, J. M., Clein, J. S., Dargaville, R. J., Kicklighter, D. W., Myneni, R. B., Dong, J., Romanovsky, V. E., Harden, J., and Hobbie, J. E.: Carbon cycling in extratropical terrestrial ecosystems of the Northern Hemisphere during the 
20th century: a modeling analysis of the influences of soil thermal dynamics, Tellus B, 55, 751-776, 2003.

Zhuang, Q., Melillo, J. M., Kicklighter, D. W., Prinn, R. G., McGuire, A. D., Steudler, P. A., Felzer, B. S., and $\mathrm{Hu}$, S.: Methane fluxes between terrestrial ecosystems and the atmosphere at northern high latitudes during the past century: A retrospective analysis with a process-based biogeochemistry model, Global Biogeochem. Cy., 18, GB3010, doi:10.1029/2004gb002239, 2004. 